\title{
Impact of Global Value Chains on Employment in India
}

Karishma Banga

University of Cambridge, Cambridge, United Kingdom

\begin{abstract}
With Global Value Chains increasingly shaping the current economic and political landscape, it has become vital to understand their implications for developing economies. This study covers the manufacturing, services, and agricultural sectors. Moreover, it examines the industry-level impact of participation in Global Value Chains on employment growth during 1995 2011. Using methodologies of fixed effects and generalized method of moments, it analyzes how increasing Foreign Value Added in output, Foreign Value Added in exports (backward linkages), and Domestic Value Added in exports of intermediate goods (forward linkages) can affect employment growth. The results reveal that higher backward linkages have negatively influenced employment growth, more so in the nonmanufacturing industries of India. However, higher forward linkages did not have any statistically significant impact on employment. In conclusion, with higher backward linkages displacing domestic labor and higher forward linkages not being able to boost employment, the net effect of Global Value Chains participation on employment growth in Indian industries has been negative.
\end{abstract}

JEL Classifications: F160, F140, F660

Keywords: Global Value Chains, Employment in India, Generalized Method of Moments, Trade in Value Added

\footnotetext{
* Corresponding Author: Karishma Banga; University of Cambridge, Faculty of Economics, The Austin Robinson Building, Sidgwick Ave, Cambridge CB3 9DD, United Kingdom; Tel: +44 (0) 7500622956, E-mail: karishma.banga24@ gmail.com.
} 


\section{Introduction}

Since September 2014, the Indian government has adopted the core policy initiative of Make in India in a national attempt to productively integrate into the global economy. Following this, greater emphasis has been placed on foreign and local investments to transform India into a global manufacturing powerhouse. With the aim of improving employment rates and skill enhancement, this programme is considered to be a major step in further integrating India into the global economy, which is increasingly being defined by Global Value Chains (GVCs).

Tracing its origins to the rise of Japan and the flying geese pattern of development in the East Asian region in the 1950s, GVCs can be simply understood as fragmentation and dispersion of economic activities, with different countries undertaking specialized tasks in the production of a final good (Trimmer 2014). Considering the increase in trade in such complex networks and the challenges faced by developing countries in linking into and upgrading within GVCs, the trade-led-development debate needs to be revisited. The literature has traditionally captured the impact of integrating into value chains using trade data for manufacturing industries to construct ratios for export and import penetration. However, these ratios are riddled with problems of double counting, in which the value of an intermediate product is captured more than once while crossing international boundaries. The drawback of using such trade data is further highlighted in the present economic scenario wherein the share of trade in tasks is increasing and services are occupying an important position in value chains (Deardorff 2011).

For developing countries, such as India, raising industrial employment has always been a policy challenge. The share of India's manufacturing sector in employment was virtually stagnant in the 1980s, but it grew in the 1990s following the trade liberalization reforms of 1991 (Goldar 2000). However, over the last decade, there has been a slow growth of manufacturing employment, giving rise to serious concerns. The services sector has fared better, with an increasing sectoral share in gross domestic product and total employment. With India launching national programmes, such as Make in India (2014), to increase its participation in GVCs, understanding the manner in which trade occurs in GVCs and its employment effects is important.

To explain the increasingly fragmented nature of production and offshoring under GVCs, Baldwin and Venables (2013) recently proposed the theory of snakes and spiders. A snake-like movement refers to a linear movement in which goods move sequentially, 
with value being added at each stage of production. In contrast, a spider-like movement captures the coming together of different parts and components without any particular order. Most value chains demonstrate a combination of these two types of movements. The structure of value chains is decided by the interaction of two forces: differences in international costs leading to dispersion of activities and the unbinding costs of shipping, management, and coordination that bind these activities together. These forces can have important implications for employment.

Given the expanding labor dimensions of trade under GVCs, this study empirically estimates the impact of participation in GVCs on industry-level employment in the Indian labor market. Furthermore, it adds to the existing literature in two important ways: 1) It empirically estimates a dynamic labor demand equation using industry-level data on value-added trade and linkages in GVCs during 1995 2011; 2) The analysis is not restricted to only the manufacturing sector but extends to 19 services subsectors and agriculture and allied activities.

First, the primary national database from the Annual Survey of Industries (ASI) and tariff data from UN-Comtrade are used to capture the impact of falling input tariffs on manufacturing employment. However, since this database does not capture the impact of value-added trade flows and excludes services from analysis, the second dataset World Input-Output Tables (part of World Input-Output Database (WIOD)) is used to measure the foreign value-added content of output. Finally, the Trade in Value Added (TiVA) database is used to estimate the impact of forward and backward linkages in GVCs on employment. The dependent variable used in the labor demand equation is total persons engaged, ${ }^{1}$ and the analysis is undertaken for 35 subsectors in WIOD and 18 subsectors in TiVA, including the services sectors. Depending on the characteristics of the panel data, methodologies of fixed effects/random effects models and difference Generalized Method of Moments (GMM) have been applied. The standard autocorrelation tests and the Sargan/Hansen test of overidentifying restrictions have been conducted to check the validity of GMM estimations.

This paper is organized as follows. Section II briefly rviews the literature and the theoretical considerations influencing empirical work. Section III analyzes trends in Foreign Value Added (FVA) in gross exports, Domestic Value Added (DVA) in the exports of intermediate goods, and participation in GVCs to give a broad picture of India's economic position in GVCs. Thereafter, it reports value added and employment

\footnotetext{
${ }^{1}$ Total persons engaged include workers, employees, and all other working proprietors actively engaged in work.
} 
trends at the sectoral level in India. Section IV derives the labor demand equation and discusses the databases and methodologies used. Section V reports and analyzes the empirical findings. Section VI concludes the study and explores the scope of future research in GVCs.

\section{Literature Review}

\section{A. Trade and employment}

The debate on the employment impact of trade liberalization spans several decades and is nested in standard trade theories. According to the Stopler-Samuelson trade theorem (1941), more trade implies gains for the factor in abundance, i.e., a country engaging in international trade enjoys comparative advantage in the abundant factor. Given that labor is the abundant factor in most developing economies, higher exports should lead to higher employment (Papageorgiou, Choksi and Michaely 1990). Similarly, in the Heckscher-Ohlin-Samuelson (HOS) framework, employment is directed from the import sector to the more labor-intensive export sector. Contrary to the HOS theory, which suggests that trade will increase the labor intensive part of output, some trade theories suggest that trade increases the scarcity factor in developing countries. In Feenstra and Hansen's (1996) model of intra-industry trade, factors of production are skilled and unskilled labor and the authors' results reveal that trade increases demand for skilled labor.

Numerous studies on the impact of trade on employment lack consensus. Therefore, the topic remains open to empirical investigation. As evidenced in the literature, trade can impact employment through two broad channels: the scale effect and substitution effect. The scale effect refers to the use of cheaper imported inputs in the production process that boosts output and, consequently, exports. Higher exports create more employment opportunities under the scale effect of trade (Sen 2008). In general, exporting firms are found to be larger and more productive than non-exporting firms due to productivitybased self-selection and learning by exporting (De Loecker 2007). Significant learningby-exporting effects are found for Sub-Saharan Africa (Van Beisebroeck 2005) and Slovenia (De Loecker 2007). For China also, Dai et al. (2011) found exporters to be 
generally larger than other firms. Seker (2012) analyzed 43 developing economies and found that exporters as well as importers have a tendency to employ more workers than firms that are not internationalized at all. Several case studies have suggested significant employment gains from trade, such as those by Kabeer and Mahmud (2004), Nadvi and Thoburn (2004), and Kien and Heo (2008). However, trade liberalization is considered to improve competitiveness and economies of scale only under certain assumptions, such as that of perfect competition and constant returns to scale (Winters 2000).

In contrast to the scale effect, trade liberalization can encourage the import of cheaper imported inputs, consequently increasing the elasticity of substitution of labor. This effect of imported products reducing labor demand is called the substitution effect (Hasan, Mitra and Ramaswamy 2007, Rodrik 1997). As found in the study by Onaran (2008) for Austria and in the study by Feenstra and Hansan (1996) for the United States (US), import penetration has decreased employment for the developed countries as well. However, Davis and Mishra (2007) argued that the impact of imports on output depends on the nature of inputs imported. If the imported intermediates are substitutes of domestically produced goods, then imports will negatively affect output and employment; however, if the imports are complementary, then the effect may not be negative.

Existing case studies also have employed different economic methodologies in examining the employment effects of trade. Jenkins and Sen (2007) employed approaches of factor content, growth accounting, and econometric modelling to examine trade and employment. They found a crucial difference in the employed approaches between Asia and Africa. Studies have also varied with respect to the measure taken for trade liberalization. Mitra and Ranjan (2010) considered offshoring as a measure of trade and examined the effect of offshoring on a country's unemployment rate. They found that as long as perfect mobility exists between sectors, offshoring of economic activities reduces the overall unemployment rate. Other studies have considered fall in tariffs as a measure of trade liberalization (Revenga 1997, Harrison and Hanson 1999) and have found that there is no consensus on the employment effects of trade, although the same measure is used.

The divergent results of case studies raise an important point: the effects of trade liberalization may be highly country-specific (Sankaran, Abraham and Joseph 2010). In the case of India, the studies by Goldberg et al. (2010) and Topalova and Khandelwal (2011) that examined trade liberalization and firm-level productivity are considered to be important. While these studies did not focus on the labor markets, increasing firm 
productivity can have important implications on labor demand; that is, more productive firms may be hiring more workers through the scale effect on output or hiring few workers overall due to the increasing share of skilled workers in production.

\section{B. Impact of GVCs on employment}

Only recently GVCs have gained prominence in the theoretical and empirical literature. Participation of a country in GVCs is defined by its engagement with a particular part of the production process, i.e., trade in intermediary goods and services. With conventional tools of measuring trade riddled with the problem of double counting, consideration of only trade in value added in GVCs creates an important distinction between trade effects of GVCs from traditional trade effects.

For employment, value-added trade makes the relation between trade and employment much more complicated than before. As proposed by Jiang and Milberg (2013), labor dimensions associated with foreign trade have expanded beyond the domestic labor part of exports and foreign labor part of imports to also include foreign labor contained in exports, domestic labor in imports, and third-country labor associated with a country's imports. The issue gets more complicated for two reasons: 1) labor market losses due to participation in GVCs are far more visible than gains; and 2) offshoring may result in more jobs but can significantly effect the composition of labor force (De Backer 2011).

Taglioni and Winkler (2014) maintained that GVCs can benefit the labor market through three main channels: 1) the demand effects, where GVC participation increases demand for skilled labor to provide specialized services, such as Research and Development (R\&D), branding, etc.; 2) training effects, which lead firms in GVCs to provide training in technology and skill development to local participating firms, thereby increasing their productivity; and 3) labor turnover effect, with the dispersion of knowledge from the labor force of participating firms to other local firms.

Importantly, although integration within GVCs may help generate more employment through productivity and scale effects, trade in GVCs has given way to a major global reallocation of jobs. Labor-intensive manufacturing activities have been outsourced to developing countries with low-cost human resources, especially in East Asia (World Bank 2012). Furthermore, significant changes have occurred in labor force composition since the spread of GVCs (OECD 2013). This change can now be measured with the 
availability of world input-output tables. Using these, Jiang and Milberg (2013) found that the jobs created as a result of trade in GVCs accrue more to the low- and mediumskilled workers than to high-skilled labor. Of the jobs globally generated by GVCs in 2009 , they found that only $13 \%$ were high-skilled workers, whereas $44 \%$ and $43 \%$ were medium- or low-skilled workers, respectively. This shift in labor composition has been accompanied by a downward pressure on wages and the bargaining power of workers.

\section{Motivation}

GVCs are hardly a new concept, and several theories have focused on the evolution and framework of such chains. Initially, GVC analysis focused on the commercial dynamics between firms in different segments of the production chain. Now, the GVC framework goes beyond manufacturing and agriculture to include global services and draws attention to the concepts of value creation, value differentiation, and capturing higher gains from participation (Gereffi and Kaplinsky 2001). While a significant gap continues to exist between the theoretical and empirical literature related to GVCs, more focus has been placed on labor in research on GVC/GPN (Barrientos 2013, Barrientos et al. 2010, Phillips and Sakamoto 2011, Phillips et al. 2011). With theoretical literature increasingly focusing on the economic and social upgrading of workers in GVCs, an empirical estimation of the impact of linking GVCs with employment can provide useful insights.

The effects of participation may vary greatly among sectors since GVCs in different sectors employ a different mix of skilled and unskilled workers. Agriculture involves a large proportion of small-scale, low-skilled, and labor-intensive production as well as a small share of high-skilled technology-intensive work. In manufacturing, as we move to higher value-added activities (say from apparel to IT), the share of low-skilled and small-scale work declines considerably (Barrientos et al. 2010). This raises an interesting empirical challenge of examining the employment impacts of GVCs in higher value-added sectors compared with lower value-added sectors. Moreover, as shown by Baldwin's (2012) smiley curve, higher value addition and higher gains accrue to preand post-manufacturing services compared with the manufacturing sector. With this gap becoming increasingly wider, analyzing the services sectors as a source of upgrading within value chains and providing quality employment are important. This study, therefore, finds it appropriate to consider both the manufacturing and services sectors. 
To analyze the labor market implications of GVCs, this study separately examines the following measures: FVA in output, FVA in exports, and DVA in exports of intermediate goods. The TiVA database uses backward linkages to describe FVA in exports as a share of gross exports and forward linkages to describe DVA in exports of intermediate products (that become part of exports or consumption of partner country) as a share of gross exports (TiVA 2015). These linkages can have opposing impacts on labor demand. The impact of higher backward linkages is expected to depend on the type of backward linkages formed. If the FVA in exports increases total exports by complementing the domestically available intermediate products and skills, then it may lead to a higher demand for labor in an industry. However, if it substitutes domestic production, then it can lead to a lower share of DVA in exports and thereby lower labor demand. Forward linkages, on the other hand, are expected to increase labor demand.

\section{Trend Analysis}

In order to conceptualise the GVC framework and to understand the functioning of trade within global chains, we take the example of the Textile and Apparel value chain in figures 1 and 2. Figure 1 represents; value-added activities in a GVC, location of lead firms, the process of conversion of raw material to final goods and the market distribution channels. The red boxes represent the high value-added activities of textile designing, marketing of textile products and services of distribution and sales. These are provided by the lead firms (large retailers and brand owners) in the developed and advanced countries. Tasks such as cutting and sewing in the textile chain are offshored to developing countries and contracted to supplier firms on the basis their cost efficiency. These different stages in a value chain receive support from external factors such as infrastructure, finance, business information and technology services, government resources, testing and training facilities etc. 
Figure 1. A textile and apparel value chain

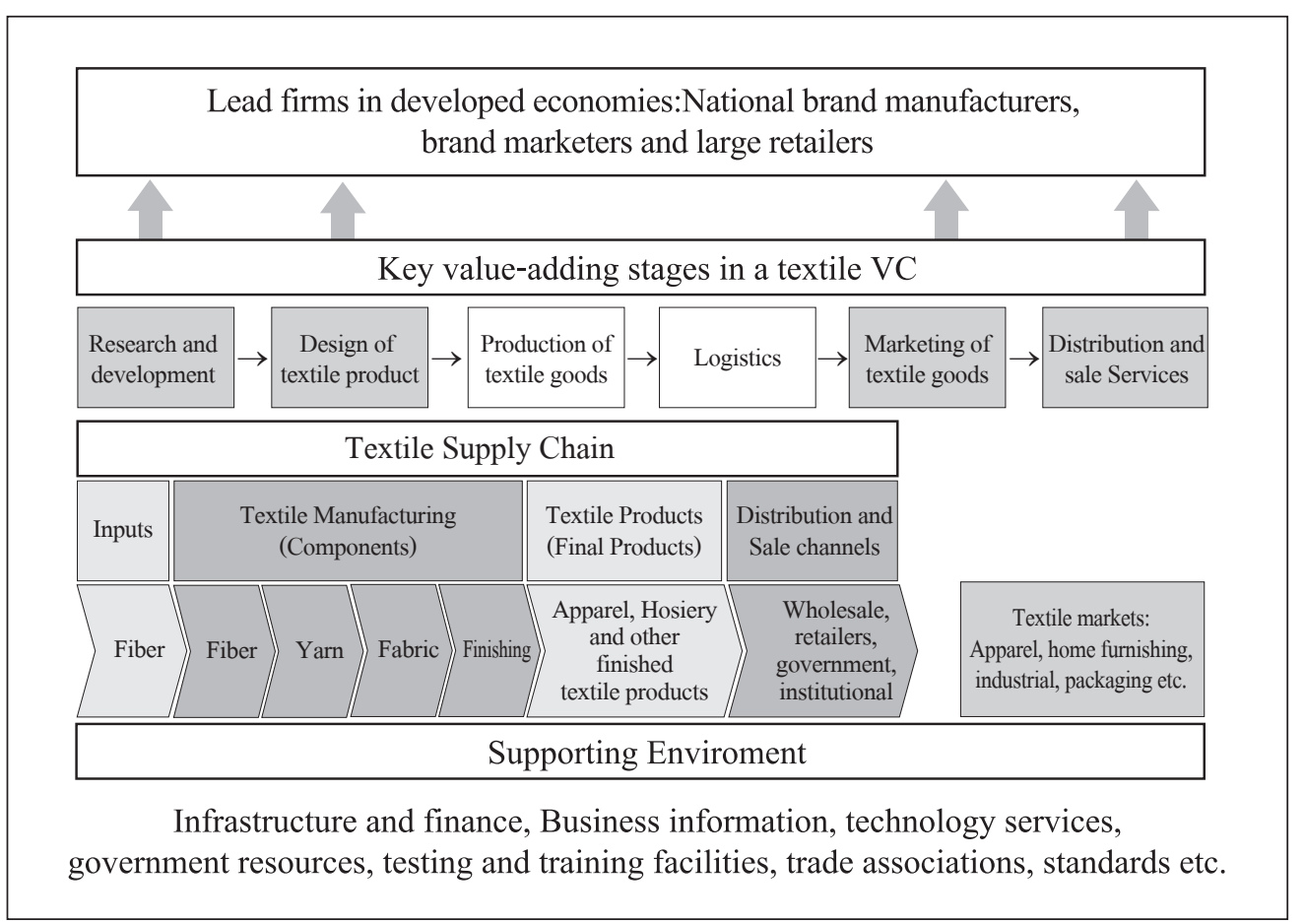

(Source) based on Frederick (2014).

In order to be part of a GVC, two types of linkages are important; backward and forward linkages, presented in Figure 2. The dark grey arrows denote backward linkages of reference country $\mathrm{B}$ or the foreign value added embodied in exports of country $\mathrm{B}$. The light grey arrows denote forward linkages of Country B, or the domestic value added of country B embodied in its exports of intermediate goods which are used for further exports by third country $\mathrm{C}$. 
Figure 2. Backward and forward linkages in a textile and apparel value chain

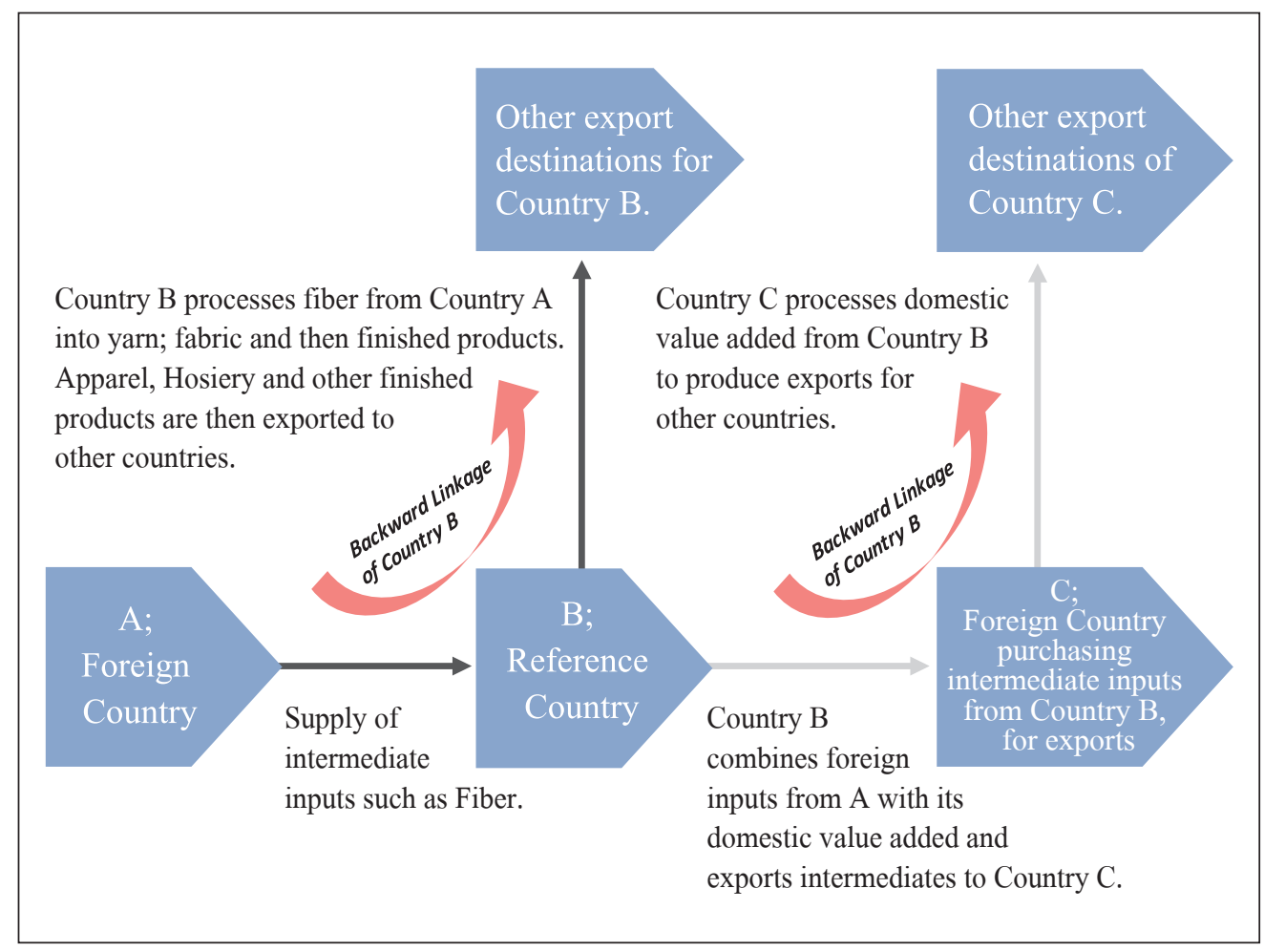

(Source) Adapted from Kowalski, P. et al. (2015).

Figure 2 demonstrates the increasing complexity of trade in GVCs, and the importance of analyzing value-added exports. Table 1 shows that while world gross exports have increased substantially since 1995, value added exports are observed to be much lower. The $24 \%$ difference in gross and value added exports in 2011 highlights the significant double counting occurring in gross exports due to the increased internationalization of trade and flow of intermediate goods across boundaries. 
Table 1. The world's gross and value-added exports

\begin{tabular}{|c|c|c|c|}
\hline Year & $\begin{array}{c}\text { Worldwide gross } \\
\text { exports } \\
\text { (US\$ millions) }\end{array}$ & $\begin{array}{c}\text { Value added } \\
\text { in gross exports } \\
\text { (US\$ millions) }\end{array}$ & $\begin{array}{c}\text { Gross exports } \\
\text { overstated by } \\
(\%)\end{array}$ \\
\hline 1995 & $5,746,092$ & $4,690,197$ & 18 \\
\hline 2000 & $7,193,891$ & $5,618,122$ & 22 \\
\hline 2005 & $11,327,230$ & $8,717,891$ & 23 \\
\hline 2008 & $17,297,953$ & $12,995,506$ & 25 \\
\hline 2009 & $13,836,157$ & $10,689,493$ & 23 \\
\hline 2010 & $16,359,136$ & $12,442,163$ & 24 \\
\hline 2011 & $19,168,055$ & $14,425,076$ & 25 \\
\hline
\end{tabular}

(Note) Calculations based on TiVA (August 2015).

\section{A. Forward linkages}

In the new TiVA (August 2015) database, forward linkage is defined as the DVA in gross exports of intermediate products that can be exported or consumed by a partner country as a share of gross exports. Notably, while gross exports have grown substantially, the growth of forward linkages has been much slower. In fact, the share of DVA in gross exports of intermediate goods has declined considerably for many developing countries during 1995 2011. Figure 3 presents the growth of forward linkages for different countries and indicates that forward linkages declined by almost $15 \%$ points in India. Similar results can be seen for Thailand, Vietnam, Chinese Taipei, and Malaysia. The declines in forward linkages for the United Kingdom (UK) and US have been relatively lower at $5 \%$ and $3 \%$, respectively. Some countries have witnessed an increase in forward linkages, such as Malta (12\%), the Philippines (7\%), and Saudi Arabia (1\%). 


\section{Figure 3. Growth in forward linkages}

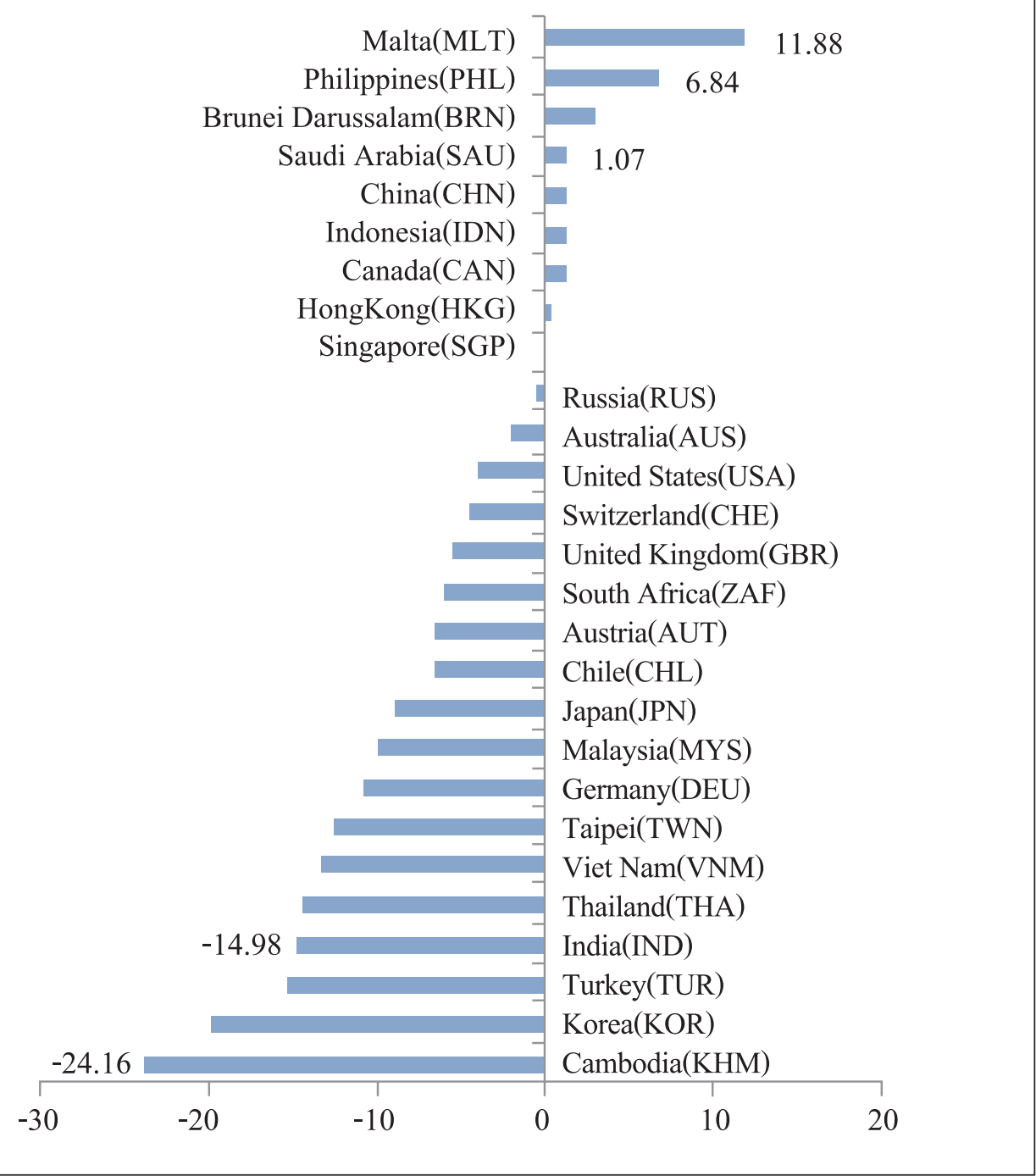

(Source) Based on TiVA (2015).

\section{B. Backward linkages}

Analysis of the FVA content of gross exports reveals an interesting picture (Figure 4). In contrast to the trend in forward linkages, the FVA content of gross exports has 
substantially increased in many countries, including India. In Brazil, Russia, India, China, and South Africa (BRICS) countries, only China reports a fall of FVA share in gross exports (1.2\%). FVA share in gross exports has increased by $3 \%$ in Brazil, $0.46 \%$ in Russia, $14.7 \%$ in India, and $6.3 \%$ in South Africa. Other countries with tangible increases in FVA share include Cambodia (24\%), Korea (19.4\%), Vietnam (14.9\%), and Malaysia (10\%). 


\section{Figure 4. Growth in backward linkages}

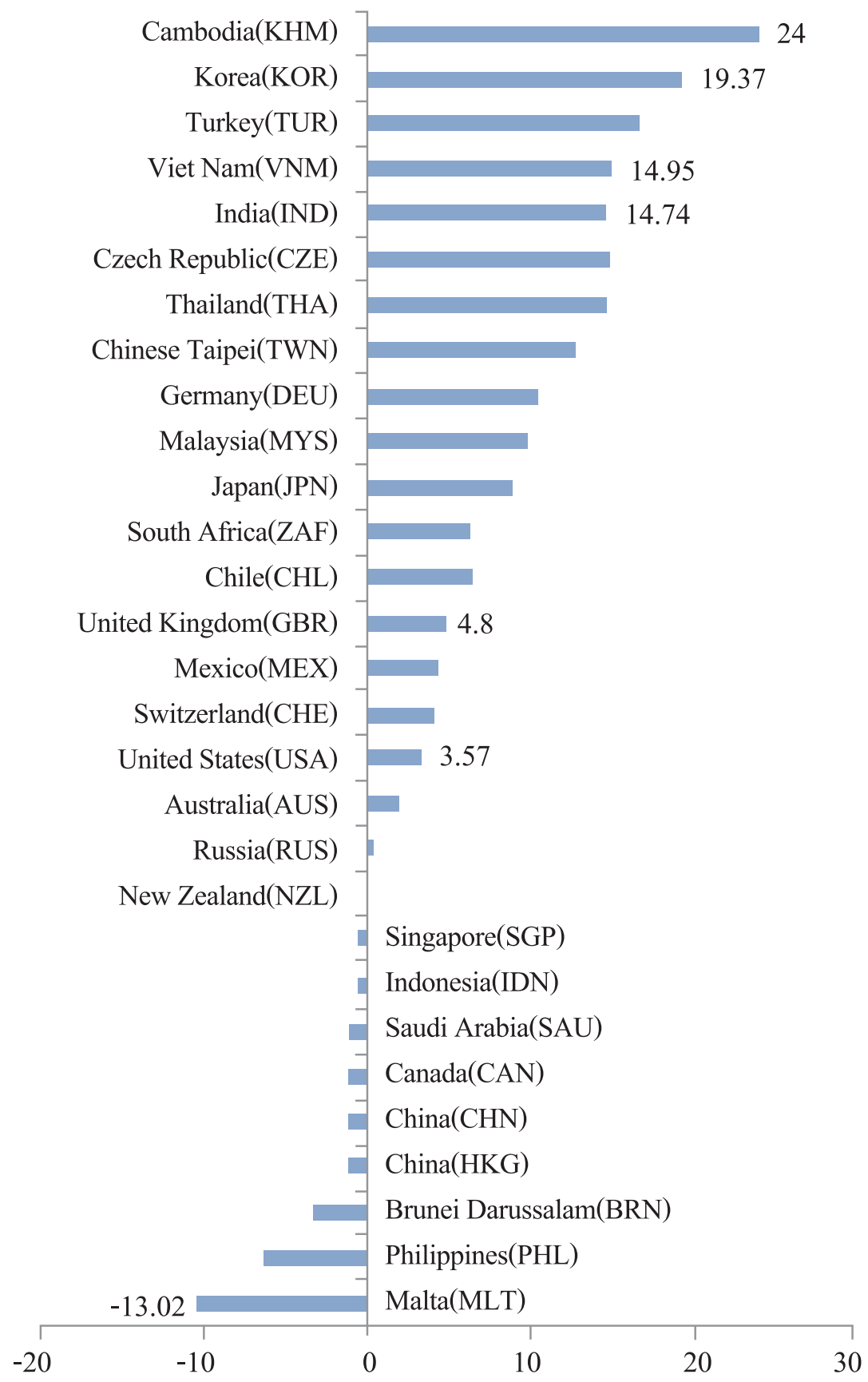

(Source) based on TiVA database (2015). 


\section{Participation in GVCs}

A country can link into global value chain through backward and forward Linkages. Based on this, the OECD-WTO database (TiVA) has defined 'participation in global value chains' as a sum of the share of foreign value added in gross exports (backward linkages) and the share of domestic value added in exports of intermediate goods (forward linkages). Using this index, participation of countries is computed for the year 2011 and depicted in column 1 of Table 2.

It is important to note that this index may not be appropriate to use for making crosscountry comparisons of GVC participation. When considering domestic value added in exports of intermediate goods, this index lumps raw materials with conventional intermediate goods and as a result may exaggerate the forward linkage measure for primary exporters. Consider the case of Saudi Arabia, which primarily exports oil. TiVA considers oil exports of Saudi-Arabia going into other countries' exports as part of Saudi Arabia's forward linkages. As the primary exporter of oil, oil exports from Saudi Arabia are consumed more than that from other countries. Therefore, when calculating participation using the TiVA index in column 1, Saudi Arabia and other primary exporters are seen to be more linked in GVCs than countries like US and UK.

Banga (2013) uses an alternative definition of 'participation in GVCs', based on a country's share in total value added created by GVCs, and calculates a country's backward and forward linkages as a share of global backward and forward linkages. Based on this index, Banga (2013) finds that in 2009, maximum value-added generated in GVCs accrued to the OECD countries (66\%), with BRICS lagging behind with $14 \%$. Using Banga's method, we calculate a country's share in total value added generated in the year 2011. This is shown in column 2 of Table 2. 
Table 2. GVC participation of countries in 2011

\begin{tabular}{|l|c|c|}
\hline \multicolumn{1}{|c|}{ Country } & $\begin{array}{c}\text { (1) } \\
\text { Participation in } \\
\text { GVCs (\%) }\end{array}$ & $\begin{array}{c}\text { (2) } \\
\text { Share in total } \\
\text { value-added (\%) }\end{array}$ \\
\hline China (People's Republic of) & 69.54 & 9.63 \\
\hline United States & 67.34 & 9.04 \\
\hline Germany & 72.5 & 7.3 \\
\hline Japan & 71.63 & 4.5 \\
\hline United Kingdom & 73.48 & 3.82 \\
\hline Russia & 86.49 & 3.5 \\
\hline France & 68.02 & 3.39 \\
\hline Canada & 78.53 & 2.89 \\
\hline Saudi Arabia & 92.81 & 2.38 \\
\hline India & 69.19 & 2.22 \\
\hline Chinese Taipei & 82.6 & 1.95 \\
\hline Mexico & 76.97 & 1.88 \\
\hline Australia & 81.66 & 1.86 \\
\hline Singapore & 79.71 & 1.55 \\
\hline Brazil & 72.49 & 1.5 \\
\hline Malaysia & 79.89 & 1.49 \\
\hline Thailand & 73.16 & 1.29 \\
\hline Indonesia & 75.93 & 0.03 \\
\hline Hong Kong, China & 65.95 & 0.58 \\
\hline Brunei Darussalam & 92.91 & \\
\hline Cambodia & 61.84 & 0.19 \\
\hline
\end{tabular}

(Note) Columns 1 and 2 are constructed using the TiVA database 2015. In column 1, GVC participation is calculated as (forward linkages + backward linkages/gross exports)*100. Column 2 calculates share of country in value-added using the formula (forward linkages + backward linkages of a country/ global forward linkages + global backward linkages)*100.

(Source) Based on TiVA database (2015). 
Column 2 finds that advanced economies like United States, United Kingdoms, France and Germany have a higher value-added share than developing countries like India, Malaysia, Singapore, Brazil and Mexico. With China emerging as the country with highest participation, and drastic differences in the participation of Brunei Darussalam and Saudi Arabia in the two tables, it is important to note that relative distribution of gains in GVCs depends on how participation is defined.

If gains are measured in terms of 'net value-added' by participation in GVCs, then Banga (2013) proposes calculating a ratio of forward to backward linkages to estimate the extent of net gains. A ratio greater than 1 implies that a country's domestic valueadded in intermediate exports is higher than its foreign-value added content of gross exports. Using TiVA 2013, Banga (2013) finds that this ratio is 0.93 for India in 2009, indicating that India's net gains from linking have not been positive.

An important distinction in the 2015 version of TiVA (compared to earlier versions) is that the forward linkages are now defined as export of domestic value added to a third country, which can be either consumed or exported by the third country. The earlier version only included that part of value added exports of a country which entered the exports of the partner country. As a result, for a given year, the absolute value of forward linkage of many countries has significantly risen in the newer version of TiVA as compared to the earlier one. Since there has been no change in the reporting of backward linkages, calculations of the ratio of forward to backward linkage may differ according to the database used.

Using TiVA (Oct, 2015), it is found that while the ratio for India is greater than one for the time periods considered (Table 3), it has declined over time which may be indicative of falling net gains.

Table 3. Ratio of forward to backward linkage for India

\begin{tabular}{|c|c|c|c|c|c|c|c|}
\hline Type of linkage & 1995 & 2000 & 2005 & 2008 & 2009 & 2010 & 2011 \\
\hline Forward & 44.1 & 45.4 & 47.1 & 45.6 & 44.7 & 46.5 & 45.0 \\
\hline Backward & 9.3 & 11.2 & 17.4 & 22.6 & 20.9 & 22.3 & 24.1 \\
\hline Ratio & 4.74 & 4.05 & 2.71 & 2.02 & 2.14 & 2.09 & 1.87 \\
\hline
\end{tabular}

(Source) Calculations based on TiVA (2015). 


\section{India and the GVCs: sectoral analysis}

Calculating the share of agriculture, total manufactures, and total services in forward linkages, it is observed that the manufacturing sector share declined from 43\% in 1995 to $37 \%$ in 2011 while that of services rose from $41 \%$ to $53 \%$ (Figure 5 ). In contrast, the share of manufacturing in backward linkages rose significantly from $13 \%$ to $36 \%$ and that of services doubled from $6 \%$ to $12 \%$ (Figure 6).

Figure 5. Forward linkages in different sectors

DVA in exports of intermediate goods / gross exports

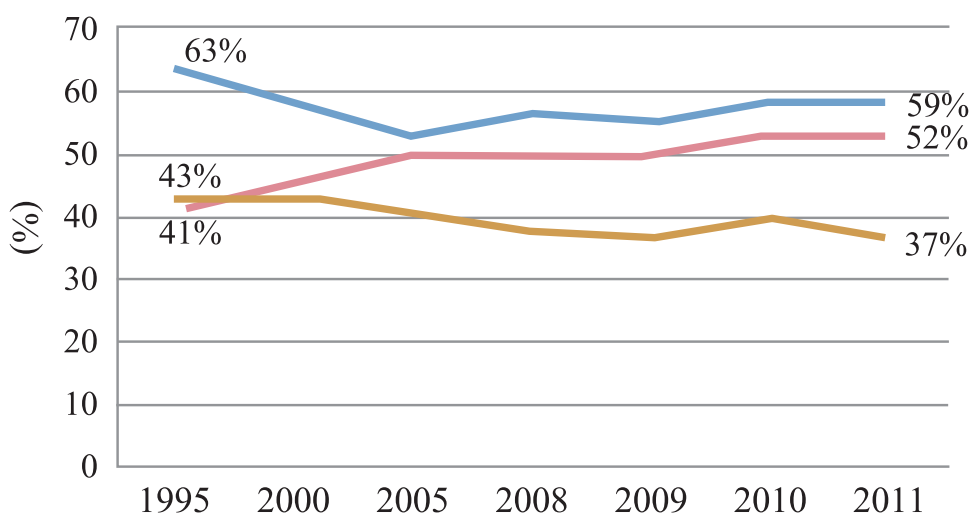

Agriculture, hunting, forestry and fishing

Manufactures

Services

(Note) DVA is domestic value added.

(Source) Based on TiVA (2015). 


\section{Figure 6. Backward linkages in different sectors}

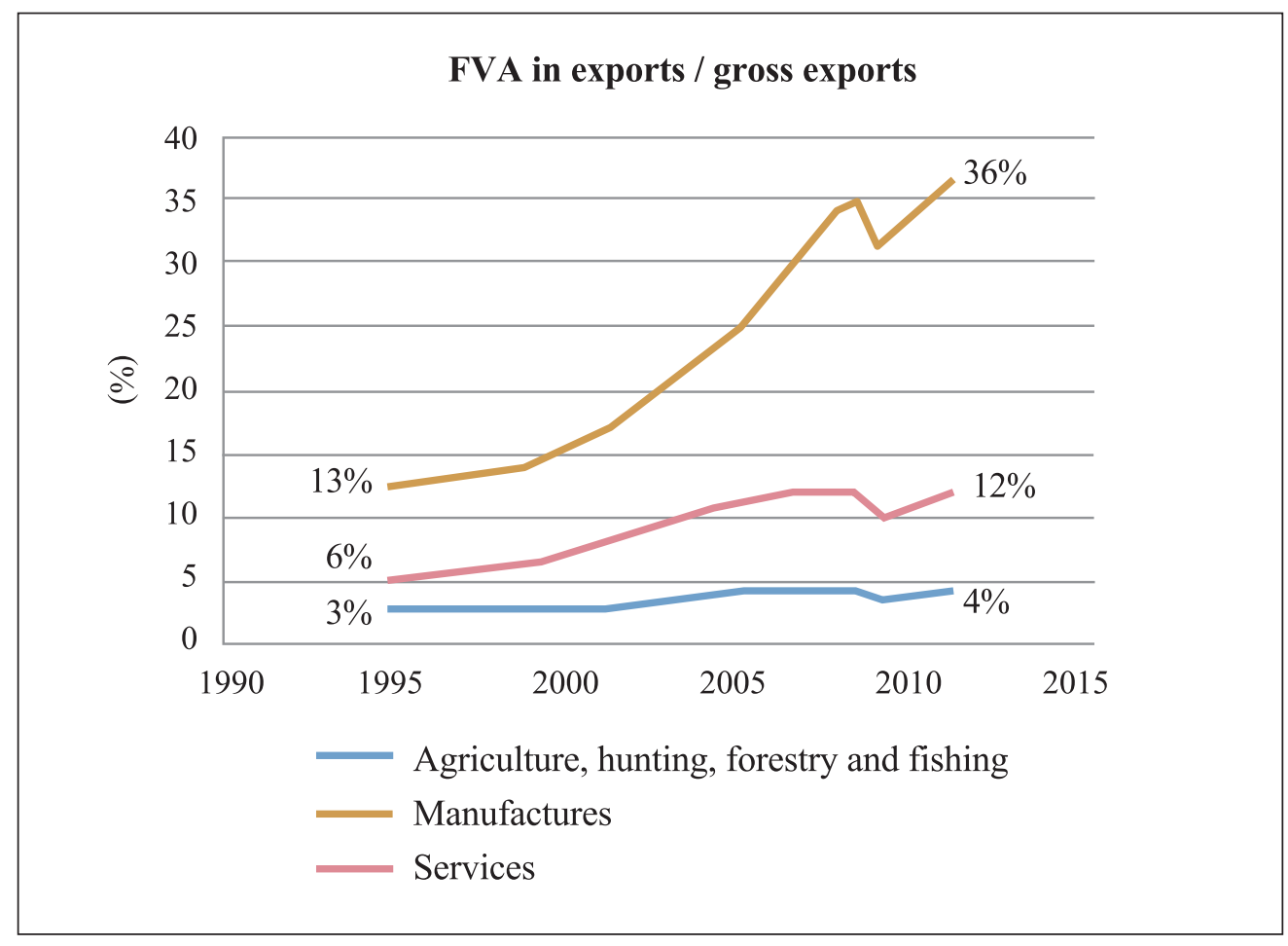

(Note) FVA is foreign value added.

(Source) based on TiVA (2015).

For business services sectors in particular, the highest growth in backward linkages (1995 2011) is observed to be in post and telecommunications, R\&D and other business activities, and transport and storage (Figure 7). For services sectors, growth in backward linkages is generally found to be significantly higher than growth in forward linkages. For R\&D and other business services, forward linkages have actually declined over time (TiVA 2015). 


\section{Figure 7. Backward linkages growth in business services}

(\% change in backward linkages)

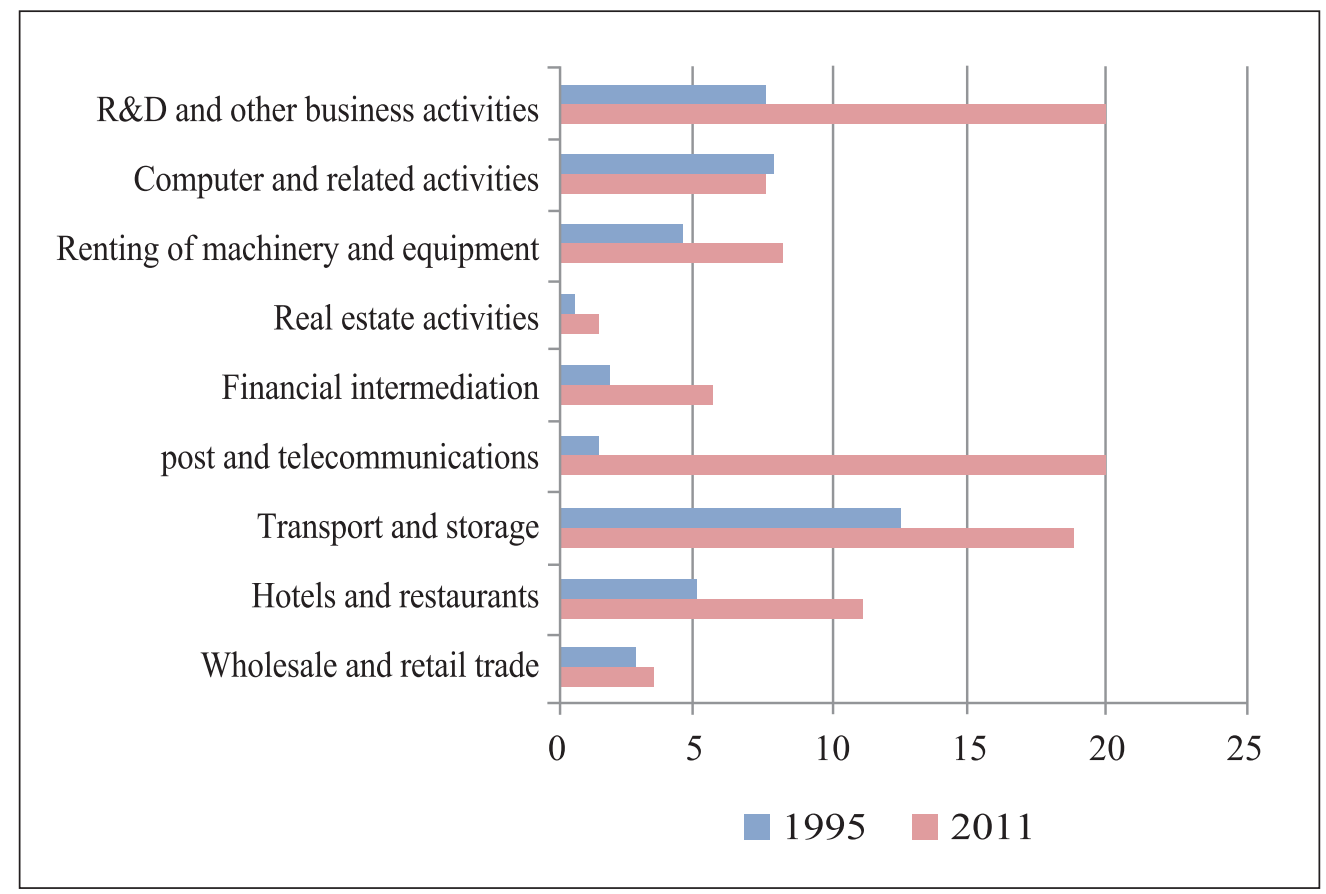

(Source) TiVA (2015).

Calculating the value-added share in gross exports for foreign and domestic services, it is found that the foreign services has increased by roughly $8 \%$ for industries and $4.5 \%$ for services (Figure 8 ). In contrast, the value-added share of domestic services has dropped dropped a little little over time (Figure 9). 
Figure 8. Foreign services value-added share in gross exports

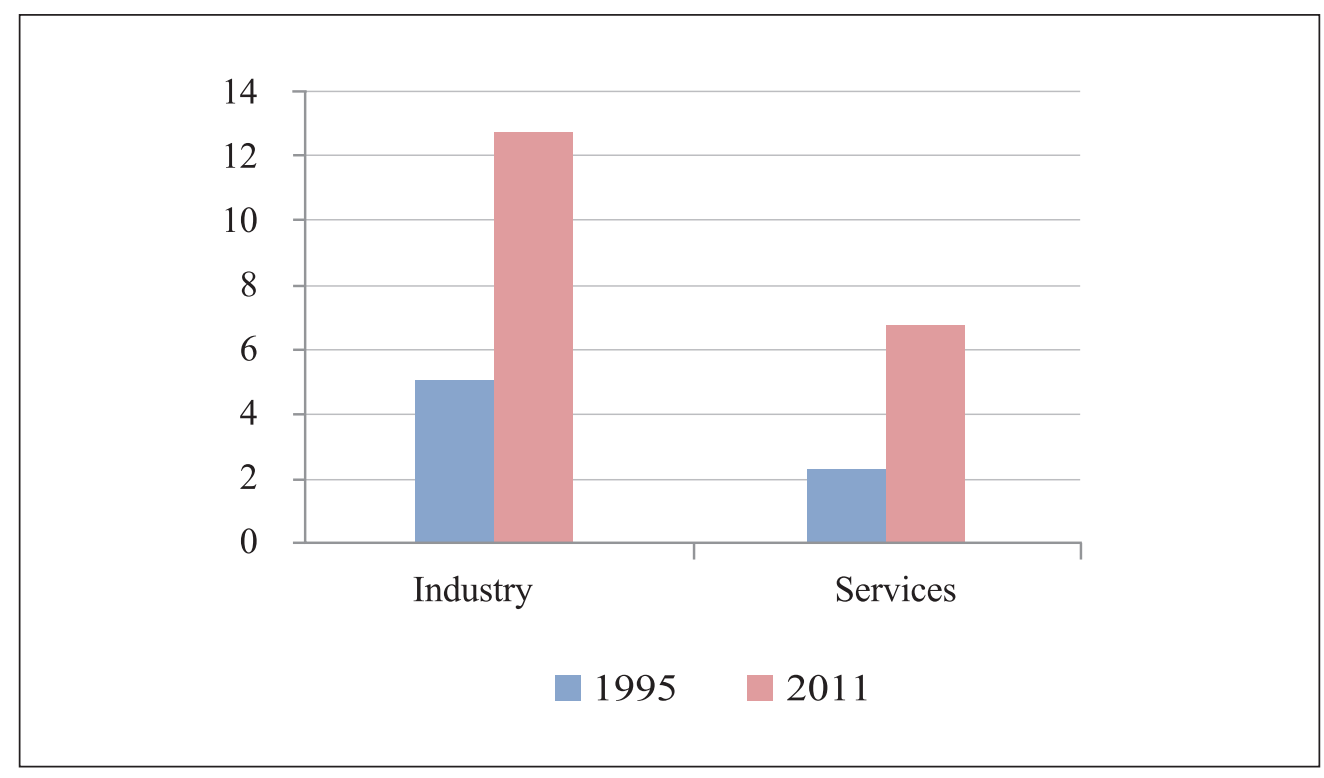

(Note) Industry comprises of manufacturing industries, mining and utilities.

(Source) TiVA (2015).

Figure 9. Domestic services value-added share in gross exports

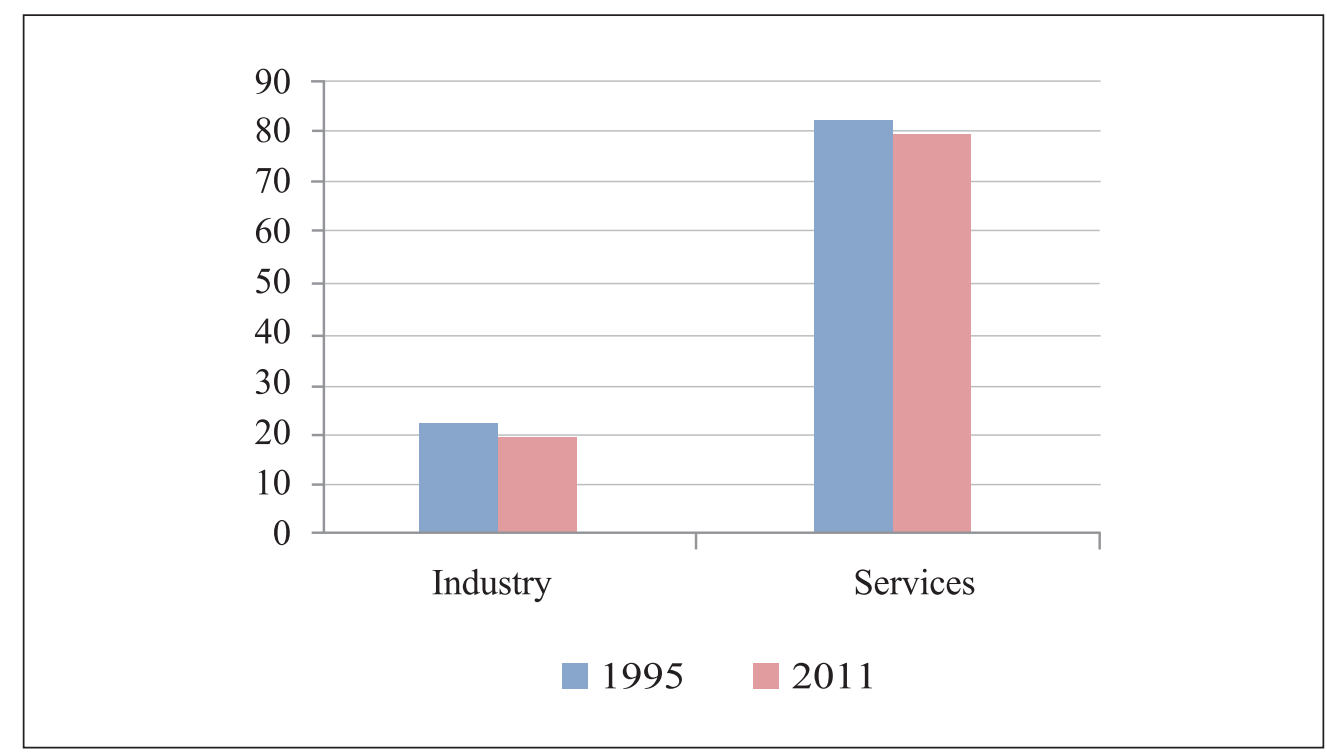

(Note) Industry comprises of manufacturing industries, mining and utilities.

(Source) TiVA (2015). 


\section{E. Trends in employment in India}

To analyze employment trends in India, reporting some of the unique characteristics of the Indian labor market is important. A large share of India's labor market comprises the informal sector, which is prevalent in both the manufacturing and services sectors. Moreover, significant labor market rigidities exist in India due to strict labor market regulations (such as those regulating hiring and dismissal) and the minimum wage rate.

Compared with 1995, sectoral employment has changed significantly in services and agricultural sectors while that of the manufacturing sector has remained more or less constant. Furthermore, 2011 witnessed 7\% increase in employment in the services sector, $1 \%$ increase in manufacturing, and $4 \%$ increase in quarrying and mining.

\section{Figure 10. Change in sectoral employment}

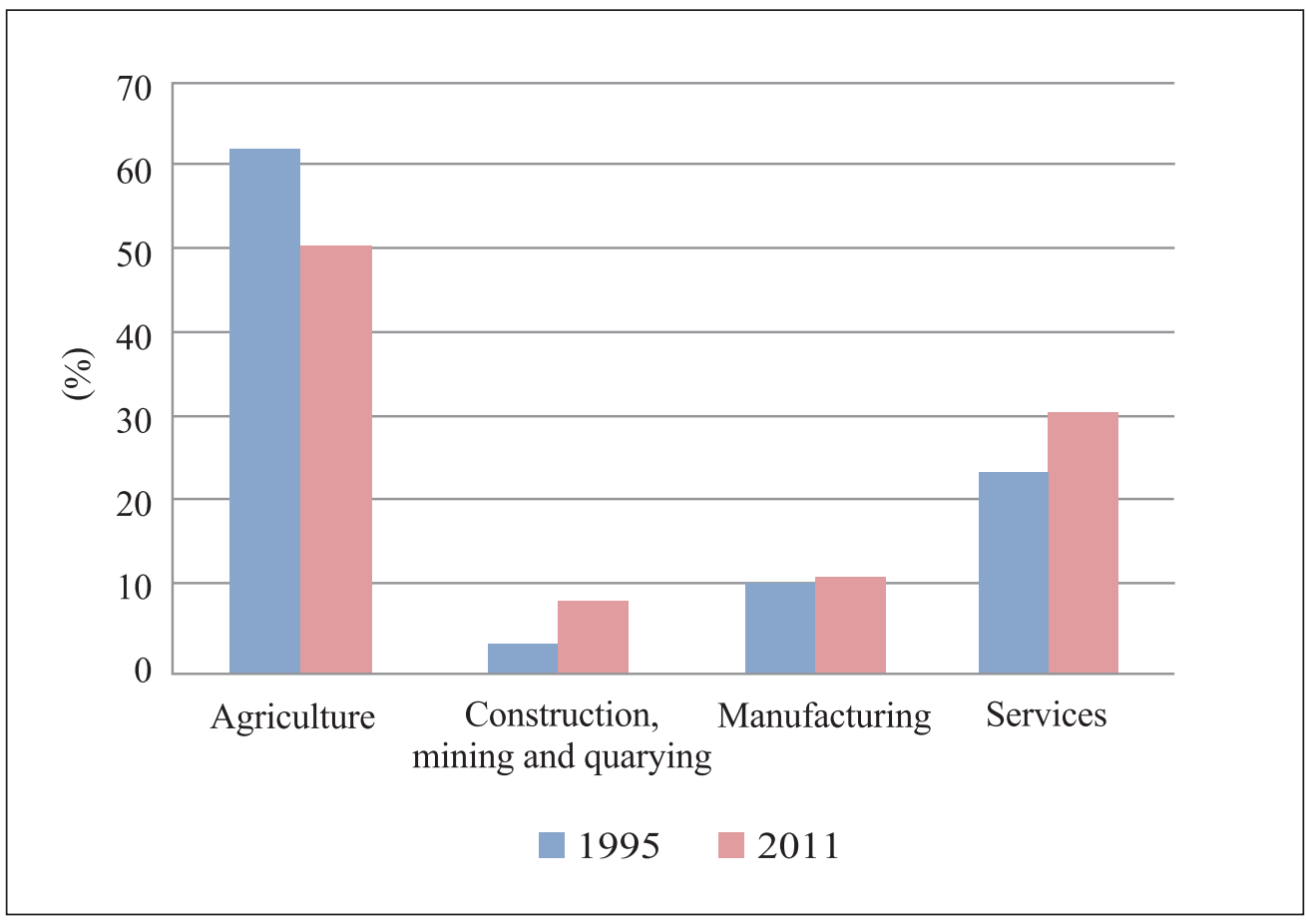

(Source) Based on Socio Economic Accounts in WIOD.

Total employment in the organized manufacturing sector considered in this study remained almost stagnant. Labor-intensive industries continue to be food products, 
textiles, basic metals, other non-metallic products and wearing apparels, which are also export-oriented industries.

\section{Data and Methodology}

\section{A. Derivation of labor demand equation}

In the derivation of the empirical model, this study closely follows Greenway et al. (1998) and Hasan et al. (2007). A Cobb-Douglas production function is assumed, which for industry $i$ in period it is given by $Q_{i t}=A^{\gamma} K_{i t}^{\alpha} L_{i t}^{\beta}$ where $Q$ denotes real output, $K$ denotes capital stock, and $L$ represents units of labor used in production. The efficiency of the production is represented by $A$, which captures the impact of demand shifters, such as exports, imports, $R \& D$, etc. $\gamma$ corresponds to factors changing the efficiency of production, and the shares of capital and labor are given by $\alpha$ and $\beta$, respectively.

For a profit-maximizing firm, labor and capital inputs are employed until the marginal product of labor equals the wage and the marginal product of capital equals the cost of capital.

Simultaneously solving the equations yields the following expression for output of the industry:

$$
Q_{i t}=\left(A^{\gamma} \frac{\alpha L_{i t}}{\beta} \frac{w_{i t}}{c}\right)^{\alpha} L_{i t}^{\beta}
$$

Taking logs of Equation (1) and rearranging terms gives us

$$
\ln L_{i t}=\chi_{0}+\chi_{1} \ln \left(\frac{w_{i t}}{c}\right)+\chi_{2} \ln \left(Q_{i t}\right)
$$

where $\chi_{0}=-\left(\frac{\gamma \ln A+\alpha \ln \alpha-\alpha \ln \beta}{\alpha+\beta}\right), \chi_{1}=\frac{-\alpha}{\alpha+\beta}$ and $\chi_{2}=\frac{1}{\alpha+\beta}$.

Allowing the efficiency of production $(A)$ to change over time, we get the following expression: 


$$
A_{i t}=e^{\omega_{0} T_{i}} M_{i t}^{\omega_{1}} X_{i t}^{\omega_{2}}
$$

where $\omega_{0} \omega_{1} \omega_{2}>0, T=$ time trend, $M=$ import penetration, and $X=$ export penetration.

Now, substituting for $A_{i t}$ in Equation (2), we get

$$
\text { with } \chi_{0}^{*}=-\left(\frac{\alpha \ln \alpha-\alpha \ln \beta}{\alpha+\beta}\right), \varphi_{0}=\varphi \omega_{0,}, \varphi_{1}=\varphi \omega_{1,}, \varphi_{2}=\varphi \omega_{2,} \text {, and } \varphi=\frac{\gamma}{\alpha+\beta} \text {. }
$$

Since the labor market in India is quite rigid, it is important to augment Equation (4) to account for costs related to employment adjustments. This can be done by estimating the following general dynamic labor demand Equation (5):

$$
\begin{aligned}
\ln L_{i t}=\lambda_{i}-\varphi_{0} T & -\sum \varphi_{1} \ln M_{i, t-j}-\sum_{j} \varphi_{2 j} \ln X_{i, t-j} \\
& +\sum_{j} \chi_{0 j} \ln L_{i, t-j}+\sum_{j} \chi_{1 j} \ln \omega_{i, t-j}+\sum_{j} \chi_{2 j} \ln Q_{i, t-j}+e_{i t}
\end{aligned}
$$

where $L_{i t}$ denotes total employment in industry $i$ at time $t, w_{i t}$ denotes the average real wage rate, $Q_{i t}$ denotes the real output produced by industry $i$ in time $t$, and $\lambda_{i}$ represents industry-specific fixed effects. In first difference GMM estimation, Equation (5) is estimated in first differences to remove industry-specific fixed effects, $\lambda_{i}$.

This study uses Equation (5) for empirical analysis but makes three important alterations according to the main aim of the study: (i) instead of taking growth in import penetration as an explanatory variable, it examines the impact of FVA imports in output and FVA imports in exports (backward linkages) on employment growth. Similarly, (ii) instead of taking export penetration, the study uses DVA in exports of intermediate goods (forward linkages). Finally, (iii) the study uses the variable gross value added rather than gross output.

\section{B. Data}

\section{Annual survey of industries}

The labor demand equation is first estimated using the primary national database, ASI. Using concordance tables provided by the Economic and Political Weekly 
Research Foundation database, a continuous time series of relevant variables is obtained for 22 manufacturing industries at a two-digit industry-level NIC 1998 classification during 1998 2011. These variables include the total number of persons engaged, gross value added, and wages and salaries across all industries. To construct the variable wage rate, wages and salaries of persons engaged in each industry is divided by the number of persons employed in that industry. The data are adjusted according to 1993 1994 prices using a suitable Wholesale Price Index. Data on average tariff rates for Indian industries are collected from World Integrated Trade Solution (TRAINS), using the International Standard Industrial Classification of All Economic Activities (ISIC) revision 3, which is then matched to the NIC 1998 classification using the concordance tables.

\section{World input-output database}

Input-output data are collected from the World Input-Output Tables for 35 industries (including services) and compatible with the two-digit industry-level ISIC revision 3. By categorizing imports into country and industry-specific categories, intermediate inputs can be traced back to the country and industry of origin, thereby giving a clearer picture of trade flows. Data on employment are collected using the Socio Economic Accounts, which give continuous time-series data for 35 industries during 1995 2009 for the variables total persons engaged, labor compensation, gross value added, and share in labor compensation according to skill level.

\section{Trade in value added}

To understand the impact of trade in GVCs, value-added data are needed for two types of trade flow: backward and forward linkages. In this aspect, the TiVA was launched by the OECD-WTO in 2013. The August 2015 version of TiVA contains derived value-added measures for 58 economies (34 OECD countries, BRICS, and rest of the world) for 1995, 2000, 2005, 2008, 2009, 2010, and 2011. Data collected from TiVA are matched to the Socio Economic Accounts for 26 industries, using concordance matrices, and then used to analyze the impact of increasing GVC linkages on employment across all sectors. While the 2015 version of TiVA has much potential to be explored for understanding multilateral trade flows, data are only available for discrete years, which may lead to small sample estimation. 


\section{Methodology}

\section{Random and fixed effects model}

To estimate the impact of growth in tariffs on growth in employment, both fixed and random effects models are estimated. The fixed effects model is chosen for analysis on the basis of the standard Hausman specification test, which returned a significant $p$ value. The appropriate $R$ squared term is checked after model selection.

When estimating a dynamic model, there may be correlation between the lagged dependent variable and error term. In such a case, employing an Fixed Effects (FE) estimator can demean the variables and remove the individual specific fixed effects in the error term using the within transformation. However, there will still be a non-negligible correlation between the transformed lagged dependent variable and the transformed error term (Bond 2002). For dynamic panel data, especially with small $T$, a FE estimator can be inconsistent; as a result, dynamic models are estimated using GMM.

\section{Arellano-Bond difference GMM}

To deal with inconsistent estimation in dynamic panel data models, Anderson and Hsiao (1981) proposed eliminating the individual effects $\left(a_{j}\right)$ in the error term $\left(u_{i t}=e_{i t}+a_{j}\right)$ by first-differencing the data. Combining this approach with the GMM framework, developed by Hansen (1982), Arellano and Bond (1991) proposed the first-difference GMM estimator, which has been widely employed in the literature since then to arrive at asymptotically efficient estimators for dynamic panel data models.

The basic idea behind GMM estimation is to use all available moment conditions and minimize the weighted function of corresponding sample moments by giving more weight to moments that have lower variance. The optimal weighting matrix that yields the most efficient estimator, i.e., the estimator with the smallest covariance matrix, gives the two-step first-difference GMM estimator.

Therefore, applying FD-GMM to the labor demand model involves carrying out a first difference transformation to get rid of the correlation between the lagged dependent variable and error term. Even after differencing, correlation exists between the lagged difference employment term $\left(\ln L_{i, t-1}-\ln L_{i, t-2}\right)$ and the transformed error term $\left(e_{i, t}-e_{i, t-1}\right)$. To deal with the problem of endogeneity arising due to this correlation, $\ln L_{i, t-2}$ and further lags of employment can be chosen as instruments as long as $e_{i t}$ is not serially correlated. To treat potential endogeneity between the covariates due to issues of reverse 
causality and omitted variable bias, lagged values of endogenous variables can also be used as instruments.

To estimate the impact of GVC linkages on employment, this study uses FD-GMM models to capture the dynamic nature of trade flow and to deal with the problem of endogenous covariates and fixed effects (Nickel 1981). The two-step GMM estimator is estimated using the Windmeijer (2005) correction for standard errors in finite samples, and the following tests are conducted to check for the validity of GMM estimations:

1) Arellano-Bond's standard autocorrelation test to ensure no autocorrelation at $\mathrm{AR}(2)$. If there is no second-order autocorrelation, then $\ln L_{i, t-2}$ can be used as an instrument.

2) Hansen's test of overidentifying restrictions to test whether the instruments are exogenous as a group. If the null hypothesis of strict exogeneity of instrumental variables (overall validity of instruments) is rejected, then the instrumental variables estimator is biased and inconsistent.

\section{Empirical Results}

\section{A. Results using world input-output database}

Column 1 and column 2 of Table 4 report the results of the fixed effects model using ASI both without and with year dummies, respectively ${ }^{2}$. Similar results are obtained for In (GVA), with growth in gross value added associated with higher employment growth. As expected, a higher wage rate implies lower demand for labor and this effect is found to be significant in Model 1. Adding year dummies to Model 1, we find that growth in tariffs is negatively and significantly related to growth in employment. Since there is no dynamic term in Model 1 and Model 2, the coefficients can be interpreted as longterm elasticity ${ }^{3}$. The random effects Model 3 confirms the signs obtained in Model 1 and

\footnotetext{
${ }^{2}$ The industries covered in the ASI are given in the appendix.

${ }^{3}$ Long-run elasticity is calculated using the formula: short-run elasticity (one minus estimated coefficient of the lagged dependent variable in the model), and short-run elasticity is equal to estimated coefficients.
} 


\section{Model 2.}

This analysis excludes services, and studying tariffs may not provide a clear picture of the quantity of intermediate goods imported. Therefore, using WIOD and difference GMM, column 4 and column 5 estimate the impact of growth of FVA imports in output on employment growth. Estimations are carried during 1995 2009 for 35 industries ${ }^{4}$, including the agricultural sector, 16 manufacturing industries, and 14 services industries.

The lagged dependent variable is found to be significant across all models. Model 4 and Model 5 find statistical significance for GVA and wage rate, with the expected signs and similar coefficients. Therefore, these results can be considered to be robust. These models also pass the autocorrelations tests and Hansen's test of overidentifying restrictions, with insignificant $p$ values.

Model 4 results show that the short-run elasticity of employment with respect to GVA, wage rate, and FVA imports is $0.11,-0.11$, and -0.02 , respectively, whereas long-run elasticity is estimated at $0.68,-0.68$, and -0.12 , respectively. Employment is found to be more elastic with respect to these variables in the long run compared with the short run. Model 4 shows that the higher the growth in FVA in output, the lower the employment growth in that industry. To account for sector-specific effects, Model 5 adds a sector dummy (= 1 for nonmanufacturing subsectors) and an interaction term between the dummy and growth in FVA in output. It finds that the negative relation between FVA imports in output and employment does not change.

${ }^{4}$ The industries covered in the WIOD are given in the appendix. 
Table 4. Impact of FVA in output on employment

\begin{tabular}{|c|c|c|c|c|c|}
\hline Model & $\begin{array}{c}\text { Fixed } \\
\text { effects (1) }\end{array}$ & $\begin{array}{c}\text { Fixed } \\
\text { effects }(2)\end{array}$ & $\begin{array}{l}\text { Random } \\
\text { effects (3) }\end{array}$ & $\begin{array}{c}\text { DIFF- } \\
\text { GMM (4) }\end{array}$ & $\begin{array}{c}\text { DIFF- } \\
\text { GMM (5) }\end{array}$ \\
\hline $\ln ($ Employment $(-1))$ & & & & $\begin{array}{c}0.84 * * * \\
(10.9)\end{array}$ & $\begin{array}{l}0.90 * * * \\
(12.03)\end{array}$ \\
\hline $\ln (G V A)$ & $\begin{array}{l}0.49^{* *} \\
(2.44)\end{array}$ & $\begin{array}{l}0.52 * * \\
(2.27)\end{array}$ & $\begin{array}{c}0.54 * * * \\
(2.78)\end{array}$ & $\begin{array}{l}0.11 * * \\
(2.03)\end{array}$ & $\begin{array}{l}0.10 * * \\
(2.07)\end{array}$ \\
\hline $\ln ($ Wage rate $)$ & $\begin{array}{l}-0.15^{* *} \\
(-2.09)\end{array}$ & $\begin{array}{c}-0.09 \\
(-1.07)\end{array}$ & $\begin{array}{l}-0.21 * * * \\
(-2.48)\end{array}$ & $\begin{array}{l}-0.11 * * \\
(-2.55)\end{array}$ & $\begin{array}{l}-0.09 * * * \\
(-2.62)\end{array}$ \\
\hline $\ln ($ tariffs $)$ & $\begin{array}{c}-0.11 \\
(-0.69)\end{array}$ & $\begin{array}{l}-0.24 * * \\
(-2.03)\end{array}$ & $\begin{array}{c}-0.07 \\
(-1.57)\end{array}$ & & \\
\hline $\ln (F V A$ in output $)$ & & & & $\begin{array}{c}-0.02 * * * \\
(-2.69)\end{array}$ & $\begin{array}{c}-0.02 * * \\
(-2.20)\end{array}$ \\
\hline $\ln \left(F V A^{*}\right.$ sector dummy $)$ & & & & & $\begin{array}{l}-0.005 \\
(-0.23)\end{array}$ \\
\hline $\begin{array}{l}\text { High skilled share in } \\
\text { compensation }\end{array}$ & & & & & $\begin{array}{c}-0.12 \\
(-1.15) \\
\end{array}$ \\
\hline Number of observations & 308 & 308 & 308 & 438 & 438 \\
\hline Number of industries & 22 & 22 & 22 & 35 & 35 \\
\hline Year dummies & No & Yes & Yes & Yes & Yes \\
\hline$R$-squared & 0.63 & 0.65 & 0.59 & & \\
\hline $\operatorname{AR}(2)$ & & & & 0.9 & 0.9 \\
\hline Hansen $p$-value & & & & 0.13 & 0.61 \\
\hline Standard errors & $\begin{array}{l}\text { Cluster } \\
\text { robust }\end{array}$ & $\begin{array}{l}\text { Cluster } \\
\text { robust }\end{array}$ & $\begin{array}{l}\text { Cluster } \\
\text { robust }\end{array}$ & $\begin{array}{c}\text { Two-step } \\
\text { Cluster } \\
\text { robust }\end{array}$ & $\begin{array}{c}\text { Two-step } \\
\text { Cluster } \\
\text { robust }\end{array}$ \\
\hline
\end{tabular}

(Notes) (i) Value of $t$ statistics reported in parenthesis: (*) significant at $10 \%,(* *)$ at $5 \%$ and (***) at $1 \%$.

(ii) Models 1, Model 2 and Model 3 are based on ASI data and Model 4 and Model 5 on WIOD.

(iii) Time dummies used in estimation but coefficients not reported. Sectordum is a dummy variable equal to 1 for all non-manufacturing subsectors. High-skilled share in compensation is a control variable, giving share of high-skilled workers in total labor compensation.

(iv) The dependent variable is natural log of total person engaged. 


\section{B. Results using TiVA}

Since the output produced using foreign inputs can either be used as final consumption by the consumers or exported to other countries, it is important to analyze the impact of FVA in gross exports and DVA in exports of intermediates, which can be assessed as linking into GVCs through backward and forward linkages, respectively. Table 5 below uses the 2015 version of TiVA and measures the actual impact of backward and forward linkages on growth in employment of 26 sectors, including services ${ }^{5}$.

Since theory dictates that employment growth can be quite persistent and due to existence of strict hiring and dismissal policies in India, we estimate dynamic panel data models that include a lagged dependent variable on the right-hand side. All estimations in Table 6 are based on difference GMM using the xtabond 2 command but use different specifications to check for robustness.

Contrary to the theory, Table 5 finds that the first lag of the dependent variable, i.e., growth in total number of persons engaged lagged one period, is not statistically significant in explaining variation in the dependent variable. However, we still employ difference GMM because not only does the estimator allow us to control for possible persistency in employment growth, but it also enables us to instrument covariates with their lagged levels when they are suspected of endogeneity in the presence fixed effects. Other estimators in such a situation would produce biased results. Thus, using the GMM estimator, we correct for possible endogeneity in the backward and forward linkage variables by instrumenting them with lagged values. We find that all model specifications in Table 5 pass the Hansen's test of overidentifying restrictions, with insignificant $p$ values. There is also no autocorrelation at the AR(2) level, as confirmed by the insignificant $p$ values reported below.

$\ln$ (GVA) and $\ln$ (wagerate) are found to be significant across all models, with expected signs and similar coefficients. Therefore, these results can be considered to be robust. Model 1 finds a negative and statistically significant impact of Backward Linkage (BL) or share of FVA in gross exports on employment growth. Model 2 adds a sector dummy (= 1 for nonmanufacturing) and an interaction term and still finds BL to be negatively associated with employment. A higher share of FVA in gross export of an industry is thus associated with lower employment growth for that industry.

Model 2 also finds that this negative effect of backward linkages on growth of

\footnotetext{
${ }^{5}$ The industries covered in TiVA are given in the appendix.
} 
employment is higher for the nonmanufacturing sector compared with the manufacturing industries. One plausible explanation for this can be that the impact on employment in the services sector is also capturing the indirect impact on services used in the export of manufactured products, such as pre- and post-manufacturing services. Backward linkages in the manufacturing industries, on the other hand, capture FVA in exports of only the organized manufacturing sector. Another explanation could be that processing trade in the manufacturing sector may be in play. Increasing FVA imports in manufacturing exports may be displacing domestic production but also might be increasing processing exports; as a result, the employment growth in manufacturing is less negatively affected than services.

Model 3 finds that forward linkages (DVA in exports of intermediate goods as a share of gross exports) does not have a statistically significant or economically significant impact on growth of employment. Model 4 adds a sector dummy and interaction of forward linkages with the sector dummy, but the impact of forward linkages on employment growth remains insignificant. 
Table 5. Impact of GVC linkages on employment

\begin{tabular}{|c|c|c|c|c|}
\hline MODEL & $\begin{array}{l}\text { DIFF-GMM } \\
\text { (1) }\end{array}$ & $\begin{array}{l}\text { DIFF-GMM } \\
\text { (2) }\end{array}$ & $\begin{array}{l}\text { DIFF-GMM } \\
\text { (3) }\end{array}$ & $\begin{array}{l}\text { DIFF-GMM } \\
\text { (4) }\end{array}$ \\
\hline In(employ $(-1))$ & $\begin{array}{c}0.36 \\
(1.23)\end{array}$ & $\begin{array}{c}0.23 \\
(1.01)\end{array}$ & $\begin{array}{c}0.01 \\
(0.05)\end{array}$ & $\begin{array}{l}-0.01 \\
(0.08)\end{array}$ \\
\hline $\ln (G V A)$ & $\begin{array}{l}0.38^{* *} \\
(2.45)\end{array}$ & $\begin{array}{l}0.4 * * * \\
(2.65)\end{array}$ & $\begin{array}{c}0.53 * * * \\
(4.22)\end{array}$ & $\begin{array}{c}0.55^{* * *} \\
(5.32)\end{array}$ \\
\hline $\ln ($ Wage rate $)$ & $\begin{array}{c}-0.4 * * * \\
(-2.75)\end{array}$ & $\begin{array}{c}-0.48 * * * \\
(-3.83)\end{array}$ & $\begin{array}{c}-0.55^{* * *} \\
(-4.75)\end{array}$ & $\begin{array}{c}-0.54 * * * \\
(-5.51)\end{array}$ \\
\hline Backward linkages & $\begin{array}{c}-0.01^{* *} \\
(-2.35)\end{array}$ & $\begin{array}{l}-0.01 * * \\
(-2.37)\end{array}$ & & \\
\hline Forward linkages & & & $\begin{array}{l}0.001 \\
(0.47)\end{array}$ & $\begin{array}{l}0.003 \\
(0.91)\end{array}$ \\
\hline$B L^{*}$ sector dummy & & $\begin{array}{c}0.02 * * * \\
(3.06)\end{array}$ & & \\
\hline$F L^{*}$ sector dummy & & & & $\begin{array}{l}-0.01 \\
(1.26)\end{array}$ \\
\hline Number of observations & 124 & 124 & 126 & 126 \\
\hline$p$-value at $\mathrm{AR}(2)$ & 0.2 & 0.3 & 0.7 & 0.6 \\
\hline Number of lags used & 2 & 2 & 3 & 3 \\
\hline Hansen Test : $p$-value & 0.06 & 0.2 & 0.2 & 0.5 \\
\hline Standard errors & Two-step robust & Two-step robust & Two-step robust & Two-step robust \\
\hline Year dummy & Yes & Yes & Yes & Yes \\
\hline Sector dummy & No & Yes & No & Yes \\
\hline
\end{tabular}

(Notes) (i) Value of $t$ statistics reported in parenthesis: (*) significant at $10 \%,(* *)$ at $5 \%$, and $(* * *)$ at $1 \%$.

(ii) Sectordum is a dummy variable equal to 1 for all non-manufacturing sub-sectors. BL is equal to share of FVA in gross exports and FL is equal to DVA in exports of intermediate goods either consumed or exported by a third country as a share of gross exports.

(iii) The dependent variable is natural log of total persons engaged.

In understanding why forward linkages fail to boost employment growth in India, an important limitation of the study is highlighted; that is, the analysis is conducted on the basis of data at the two-digit industry level. Examining the impact of forward and backward linkages on employment growth at a much more disaggregated level is important. However, analyzing trends in GVC linkages in India can shed some light and 
provide insights on the role of forward linkages in promoting employment growth. The literature examining India's integration into the global economy suggests that unlike other developing economies that have linked into GVCs by providing labor-intensive activities, India has developed pockets of specialization in relatively skill- and capitalintensive manufacturing and services sectors (OECD 2014). India has higher backward than forward participation, and its highest GVC linkages are in the chemical and electrical equipment industries. Therefore, it is quite plausible that forward linkages in Indian industries have increased in the more capital-intensive industries and not in the labor-intensive sectors. Consequently, the impact of increasing forward linkages has not been significant on overall employment growth.

In contrast, an important finding of the study is that higher FVA in output and higher FVA in exports has significantly and adversely impacted industry-level employment growth in India. This suggests the dominance of the substitution effect of trade in the case of Indian industries. The types of inputs imported act as substitutes for domestically produced goods and labor instead of complementing production and expanding output. This effect is higher than the scale effect; thus, the net impact of higher backward linkages in Indian industries on employment growth is negative.

\section{Conclusions}

The study deals with empirically analyzing the relationship between trade in GVCs and employment in India. Empirical estimates are arrived for (a) impact of tariff liberalisation on employment growth in the manufacturing sector; (b) impact of change in foreign value added in domestic production on growth of domestic employment in all three sectors- agriculture, manufacturing as well as services; (c) the impact of backward and forward linkages on employment growth in all three sectors of Indian economy.

The impact of change in import tariffs on employment (total persons engaged) was estimated using a fixed effects model and lower import tariffs were found to be associated with higher employment. Using Difference GMM and World Input-Output Database, it is found that growth of foreign value-added in output implies lower growth in employment. Lastly, the impact of backward and forward linkages in global value chains was estimated using TiVA database. The results show a negative relationship 
between growth in backward linkages and growth in employment. This negative effect is higher for non-manufacturing industries. Growth in forward linkages is found to have statistically insignificant impact on growth in employment.

The above results are derived for India but may also be relevant for similar developing economies. For a country like India that links into the global economy through both importing and exporting, it is important to analyse the type of backward and forward linkages to create. The impact of linking into global value chains on labour demand can be multi-fold, especially through backward linkages. Backward linkages (foreign value added in exports) that are complementary to the existing domestic resources, technology and skill-level may encourage more value-addition to exports, thereby leading to growth in employment, but can prove to be challenging if they displace domestic production. In countries like India, where a broad range of goods are produced from primary products to finished goods, policies should be tailored to encourage backward linkages in those industries where the imported intermediate products do not displace the domestic supply chains. In terms of forward linkages, it is important to encourage domestic value-addition in exports of labour intensive industries such as textiles and garments. While India has managed to link into the global economy in the capital-intensive sectors, significant employment gains can be realized by boosting GVC linkages of traditional sectors. Another important avenue to secure higher rents, and upgrade in GVCs, is to increase the contribution of services in gross exports of manufacturing and agricultural sectors.

An important channel of linking into GVCs, which goes beyond the scope of the study, is integration through Foreign Direct Investment (FDI) and the role played by lead firms. The employment impacts of trade and FDI in GVCs can differ for developing economies and need to be explored further. Another caveat of the study is that the WIOD and the TiVA database provide data on trade flows at 2 digit industries only. Analysis at a more disaggregated level is important and can yield interesting results. It is also important to note that the indicators from these databases that are used in the study are based on two main assumptions; a) Production assumption and b) Proportionality assumption. While the production assumption takes all firms in an industry as using the same inputs to produce the same output, the proportionally assumption assumes that the proportion of imported intermediates is equal to the ratio of imports to total domestic demand in that product (TiVA notes, 2015). Thus, the bilateral trade estimates from these databases need to be carefully interpreted.

In spite of the above limitations, the study fills an important gap in the existing literature by undertaking an empirical estimation on GVCs and employment in India. 
It also contributes to the existing literature by covering all sectors. Empirical study on linking GVCs into an economy is still in its infancy and provides a huge potential for undertaking further research. In particular, future research areas include the role of Foreign Direct Investment in GVCs and impact of technological transfers and spillovers through GVCs. Moreover, linking into GVCs may also have implications for labour markets in terms of changes in the composition of the labour market, labour productivity, skilled and unskilled labour, wage differentials between skilled and unskilled labour, etc. These need to be explored in detail and at the most disaggregated level possible. The full use of GVCs in formulating industrial policy will be another key area for further research.

Received 11 April 2016, Revised 11 June 2016, Accepted 8 July 2016

\section{References}

Anderson, Theodore Wilbur, and Cheng Hsiao. "Estimation of dynamic models with error components." Journal of the American Statistical Association 76, no. 375 (1981): 598-606.

Arellano, Manuel, and Stephen Bond. "Some tests of specification for panel data: Monte Carlo evidence and an application to employment equations." Review of economic studies 58, no. 2 (1991): 277-297.

Baldwin, Richard E. "Global supply chains: Why they emerged, why they matter, and where they are going." (2012).

Baldwin, Richard, and Anthony J. Venables. "Spiders and snakes: offshoring and agglomeration in the global economy." Journal of International Economics 90, no. 2 (2013): 245-254.

Banga, Rashmi. "Linking into global value chains is not sufficient: do you export domestic value added contents?" Journal of Economic Integration (2014): 267-297.

Blundell, Richard, and Stephen Bond. "Initial conditions and moment restrictions in dynamic panel data models." Journal of econometrics 87, no. 1 (1998): 115-143. 
Davis, Donald R., and Prachi Mishra. "Stolper-Samuelson is dead: And other crimes of both theory and data." In Globalization and poverty, pp. 87-108. University of Chicago Press, 2007.

Deardorff, Alan V. "International provision of trade services, trade, and fragmentation." Review of International Economics 9, no. 2 (2001): 233-248.

Feenstra, Robert C., and Gordon H. Hanson. Globalization, outsourcing, and wage inequality. No. w5424. National Bureau of Economic Research, 1996.

Gereffi, Gary, John Humphrey, and Raphael Kaplinsky. "Introduction: Globalisation, value chains and development." IDS bulletin 32, no. 3 (2001): 1-8.

Goldar, Bishwanath. "Employment growth in organised manufacturing in India." Economic and Political weekly (2000): 1191-1195.

Goldar, Bishwanath. Trade liberalization and manufacturing employment: The case of India. International labour office (ILO), 2002.

Goldberg, Pinelopi K., Amit K. Khandelwal, Nina Pavcnik, and Petia Topalova. "Multiproduct firms and product turnover in the developing world: Evidence from India." The Review of Economics and Statistics 92, no. 4 (2010): 1042-1049.

Harrison, Ann, and Gordon Hanson. "Who gains from trade reform? Some remaining puzzles." Journal of development Economics 59, no. 1 (1999): 125-154.

Hasan, Rana, Devashish Mitra, and Krishnarajapet V. Ramaswamy. "Trade reforms, labor regulations, and labor-demand elasticities: Empirical evidence from India." The Review of Economics and Statistics 89, no. 3 (2007): 466-481.

Hoekman, Bernard, and L. Alan Winters. "Trade and employment: stylized facts and research findings." World Bank Policy Research Working Paper 3676 (2005).

Jiang, Xiao, and William Milberg. "Capturing the jobs from globalization: trade and employment in global value chains." Available at SSRN 2259668 (2013).

Kabeer, Naila, and Simeen Mahmud. "Globalization, gender and poverty: Bangladeshi women workers in export and local markets." Journal of international development 16, no. 1 (2004): 93-109.

Kaplinsky, Raphael, and Mike Morris. A handbook for value chain research. Vol. 113. Ottawa: IDRC, 2001. 
Kien, Tran Nhuan, and Yoon Heo. "Impacts of trade liberalization on employment in Vietnam: a system generalized method of moments estimation." The Developing Economies 47, no. 1 (2009): 81-103.

Nadvi, Khalid, John T. Thoburn, Bui Tat Thang, Nguyen Thi Thanh Ha, Nguyen Thi Hoa, Dao Hong Le, and Enrique Blanco De Armas. "Vietnam in the global garment and textile value chain: impacts on firms and workers." Journal of international development 16, no. 1 (2004): 111-123.

Nickell, Stephen. "Biases in dynamic models with fixed effects." Econometrica: Journal of the Econometric Society (1981): 1417-1426.

OECD. Publishing. Interconnected Economies: Benefiting from Global Value Chains. OECD Publishing, 2013.

Onaran, Özlem. "The effect of foreign affiliate employment on wages, employment, and the wage share in Austria." (2008).

Papageorgiou, D. Choksi, and M. AM Michaely. Liberalizing foreign trade in developing countries: the lessons of experience. no. 382.71 P213. World Bank, Washington, DC (EUA), 1990.

Revenga, Ana. "Employment and wage effects of trade liberalization: the case of Mexican manufacturing." Journal of labor Economics 15, no. S3 (1997): S20-S43.

Rodriguez, Francisco, and Dani Rodrik. "Trade policy and economic growth: a skeptic's guide to the cross-national evidence." In NBER Macroeconomics Annual 2000, Volume 15, pp. 261-338. MIT Press, 2001.

Rodrik, Dani. "Has Globalization Gone Too Far? Institute for International Economics, Washington, DC." (1997).

Roodman, David. "How to do xtabond2: An introduction to difference and system GMM in Stata." Center for Global Development working paper 103 (2006).

Sankaran, Uma, Vinoj Abraham, and K. J. Joseph. "Impact of Trade Liberalization on Employment: The Experience of India's Manufacturing Industries." Centre for Development Studies, Trivandrum (2007).

Sankaran, Uma, Vinoj Abraham, and K. J. Joseph. "Impact of Trade Liberalization on Employment: The Experience of India's Manufacturing Industries." Centre for 
Development Studies, Trivandrum (2007).

Sen, Kunal. "International Trade and Manufacturing Employment Outcomes in India." A comparative study (2008).

Sen, Kunal. "International Trade and Manufacturing Employment: Is India following the Footsteps of Asia or Africa?" Review of Development Economics 13, no. 4 (2009): 765777.

Slaughter, Matthew J. "International trade and labour-demand elasticities." Journal of International Economics 54, no. 1 (2001): 27-56.

Taglioni, Daria, and Deborah Winkler. "Making global value chains work for development." serie Economic Premise 143 (2014).

Topalova, Petia, and Amit Khandelwal. "Trade liberalization and firm productivity: The case of India." Review of economics and statistics 93, no. 3 (2011): 995-1009.

Windmeijer, Frank. "A finite sample correction for the variance of linear efficient twostep GMM estimators." Journal of econometrics 126, no. 1 (2005): 25-51.

Winters, L. Alan. "Trade liberalisation and poverty: what are the links?" The World Economy 25, no. 9 (2002): 1339-1367. 


\section{Appendix 1: Output-constrained labor demand}

Descriptive statistics

(with industry fixed effects using ASI)

\begin{tabular}{|l|c|c|c|c|c|}
\hline \multicolumn{1}{|c|}{ Variable } & Observations & Mean & Standard deviation & Min & Max \\
\hline $\ln ($ GVA $)$ & 182 & 8.54 & 1.05 & 6.01 & 10.71 \\
\hline $\ln ($ Wage rate $)$ & 182 & -0.67 & 0.95 & -2.72 & 2.08 \\
\hline $\ln ($ BL $)$ & 178 & 2.46 & 0.96 & -3.85 & 4.03 \\
\hline $\ln ($ FL $)$ & 149 & 3.67 & 1.05 & -4.61 & 4.58 \\
\hline $\ln ($ persons engaged $)$ & 182 & 8.21 & 1.43 & 4.08 & 12.5 \\
\hline
\end{tabular}

Correlation matrix

\begin{tabular}{|l|c|c|c|c|c|}
\hline \multicolumn{1}{|c|}{ Variable } & $\begin{array}{c}\ln \\
(G V A)\end{array}$ & $\begin{array}{c}\ln \\
(\text { Wage Rate })\end{array}$ & $\begin{array}{c}\ln \\
(B L)\end{array}$ & $\begin{array}{c}\ln \\
(F L)\end{array}$ & $\begin{array}{c}\ln \\
\text { (persons engaged })\end{array}$ \\
\hline $\ln ($ GVA $)$ & 1 & & & & \\
\hline $\ln ($ Wage rate $)$ & 0.28 & 1 & & & \\
\hline $\ln ($ BL $)$ & -0.37 & 0.13 & 1 & & \\
\hline $\ln ($ FL $)$ & -0.02 & 0.008 & -0.05 & 1 & \\
\hline $\ln ($ persons engaged $)$ & 0.55 & -0.55 & -0.48 & -0.07 & 1 \\
\hline
\end{tabular}

Appendix 2: GMM estimation of output-constrained labor demand equation

Descriptive statistics

(using WIOD)

\begin{tabular}{|l|c|c|c|c|c|}
\hline \multicolumn{1}{|c|}{ Variable } & Observations & Mean & Standard deviation & Min & Max \\
\hline $\ln ($ GVA $)$ & 525 & 7.97 & 1.77 & 5.25 & 10.66 \\
\hline $\ln ($ Wage rate $)$ & 525 & -0.94 & 0.88 & -3.5 & 1.69 \\
\hline $\ln ($ FVA imports $)$ & 509 & 1.87 & 1.56 & -3.5 & 5.34 \\
\hline $\ln ($ DVA exports $)$ & 418 & 3.67 & 1.05 & -4.61 & 4.58 \\
\hline $\ln ($ persons engaged $)$ & 525 & 7.98 & 1.52 & 4.08 & 12.51 \\
\hline
\end{tabular}


Correlation matrix

\begin{tabular}{|l|c|c|c|c|c|}
\hline \multicolumn{1}{|c|}{ Variable } & $\begin{array}{c}\ln \\
(\text { GVA })\end{array}$ & $\begin{array}{c}\ln \\
(\text { Wage Rate })\end{array}$ & $\begin{array}{c}\ln \\
(\text { FVA imports })\end{array}$ & $\begin{array}{c}\ln \\
(\text { DVA exports })\end{array}$ & $\begin{array}{c}\ln \\
\text { (persons engaged })\end{array}$ \\
\hline $\ln ($ GVA $)$ & 1 & & & & \\
\hline $\ln ($ Wage rate $)$ & 0.07 & 1 & & & \\
\hline $\ln ($ FVA imports $)$ & 0.3 & 0.14 & 1 & & \\
\hline $\ln ($ DVA exports $)$ & 0.19 & -0.1 & 0.56 & 1 & \\
\hline $\ln ($ persons engaged $)$ & 0.69 & -0.51 & 0.11 & 0.22 & 1 \\
\hline
\end{tabular}

\section{Appendix 3: GMM estimation of labor demand equation}

Descriptive statistics

(using WIOD and TIVA)

\begin{tabular}{|l|c|c|c|c|c|}
\hline \multicolumn{1}{|c|}{ Variable } & Observations & Mean & Standard deviation & Min & Max \\
\hline $\ln ($ GVA $)$ & 308 & 8.59 & 1.11 & 3.85 & 10.92 \\
\hline $\ln ($ Wage rate $)$ & 308 & -1.35 & 0.49 & -3.36 & 1.03 \\
\hline $\ln ($ Tariffs $)$ & 308 & 2.9 & 0.65 & 0.42 & 3.83 \\
\hline $\ln ($ persons engaged $)$ & 308 & 12.51 & 1.03 & 9.63 & 14.41 \\
\hline
\end{tabular}

Correlation matrix

\begin{tabular}{|l|c|c|c|c|}
\hline \multicolumn{1}{|c|}{ Variable } & $\begin{array}{c}\ln \\
(G V A)\end{array}$ & $\begin{array}{c}\ln \\
(\text { Wage rate })\end{array}$ & $\begin{array}{c}\ln \\
(\text { Tariffs })\end{array}$ & $\begin{array}{c}\ln \\
(\text { persons engaged })\end{array}$ \\
\hline $\ln (G V A)$ & 1 & & & \\
\hline $\ln ($ Wage rate $)$ & 0.36 & 1 & & \\
\hline $\ln ($ Tariffs $)$ & -0.18 & -0.35 & 1 & \\
\hline $\ln ($ persons engaged $)$ & 0.72 & -0.12 & 0.07 & 1 \\
\hline
\end{tabular}




\section{Appendix 4: List of ASI industries}

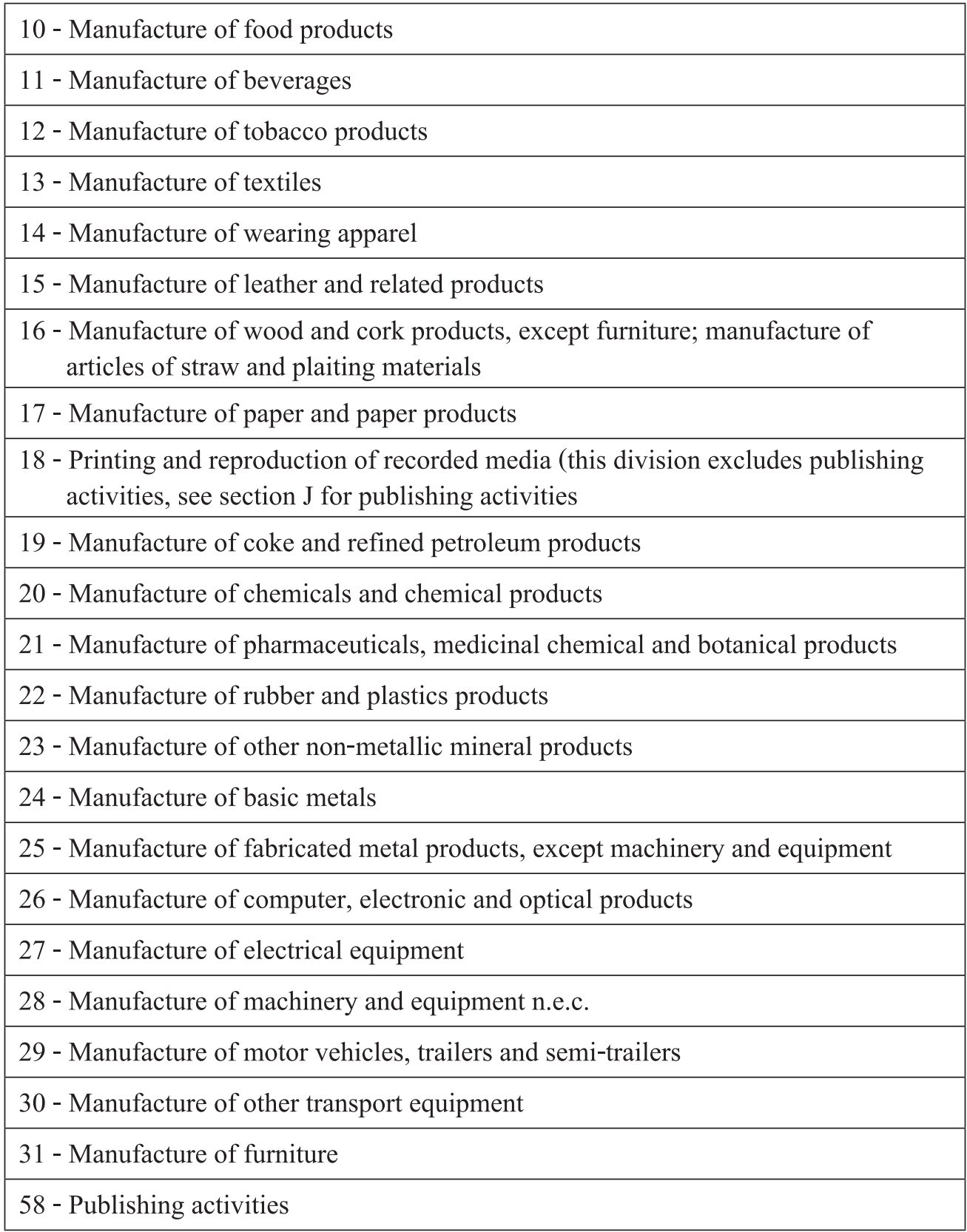




\section{Appendix 5: List of industries in WIOD}

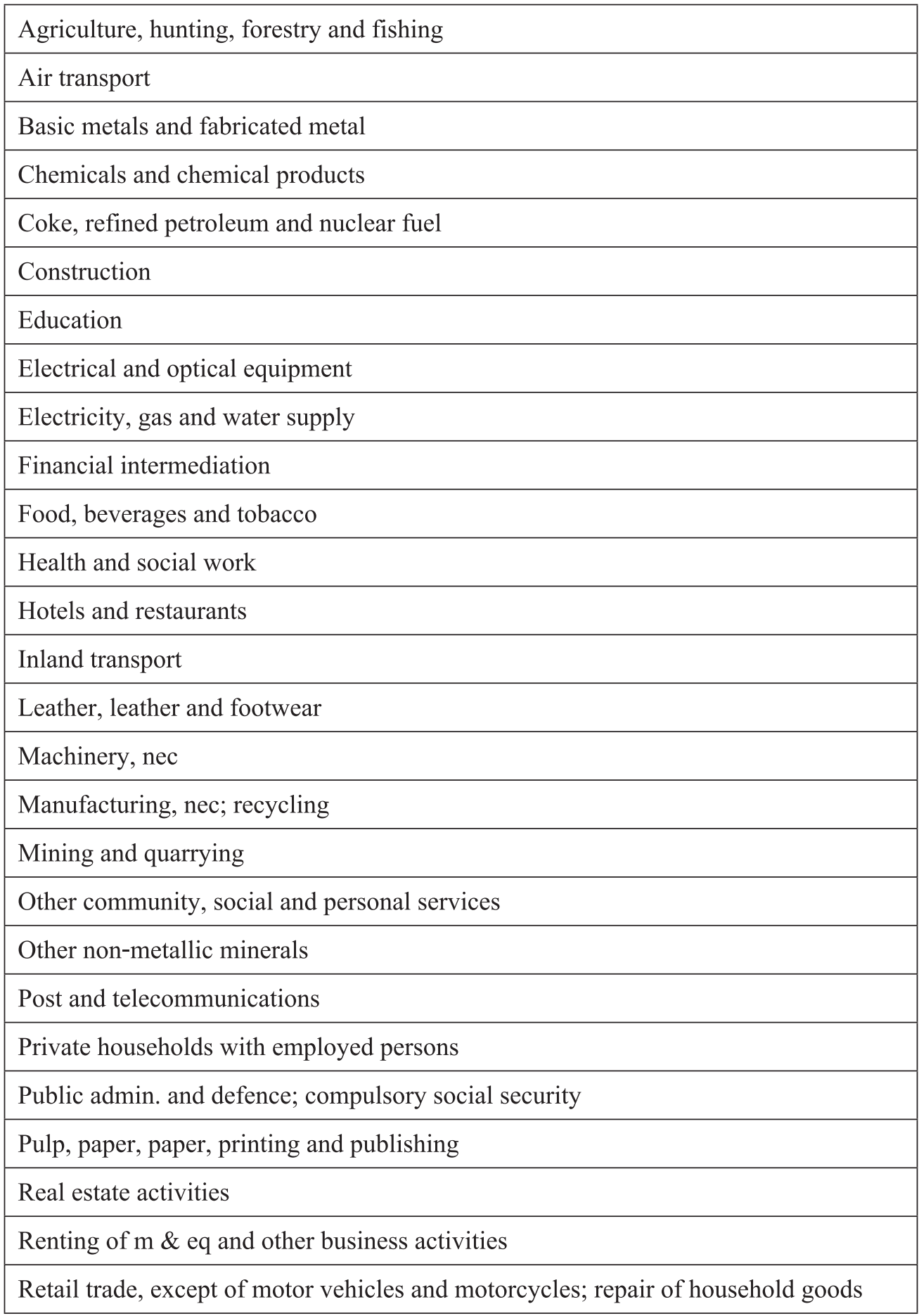




\section{Rubber and plastics}

Sale, maintenance and repair of motor vehicles and motorcycles; retail sale of fuel

Other supporting and auxiliary transport activities; activities of travel agencies

Textiles and textile products

Transport equipment

Water transport

Wholesale trade and commission trade, except of motor vehicles and motorcycles

Wood and products of wood and cork

\section{Appendix 6: Industries in TiVA}

C15T16: Food products, beverages and tobacco

C17T19: Textiles, textile products, leather and footwear

C20: Wood and products of wood and cork

C21T22: Pulp, paper, paper products, printing and publishing

C23: Coke, refined petroleum products and nuclear fuel

C24: Chemicals and chemical products

C25: Rubber and plastics products

C26: Other non-metallic mineral products

C27: Basic metals

C28: Fabricated metal products

C29: Machinery and equipment, nec

C30T33X: Computer, Electronic and optical equipment

C31: Electrical machinery and apparatus, nec

C34: Motor vehicles, trailers and semi-trailers

C35: Other transport equipment 